\title{
Article \\ Effect of Encapsulated Beet Extracts (Beta vulgaris) Added to Yogurt on the Physicochemical Characteristics and Antioxidant Activity
}

\author{
Martha A. Flores-Mancha ${ }^{1}$ (D), Martha G. Ruíz-Gutiérrez ${ }^{2}$, Rogelio Sánchez-Vega ${ }^{1}$, Eduardo Santellano-Estrada ${ }^{1}$ (D) \\ and América Chávez-Martínez ${ }^{1, *(1)}$ \\ 1 Departamento de Tecnología de Productos de Origen Animal, Facultad de Zootecnia y Ecología, Universidad \\ Autónoma de Chihuahua, Periférico Francisco R. Almada km 1, Chihuahua 31000, CI, Mexico; \\ 99azu.flores@gmail.com (M.A.F.-M.); rsanchezv@uach.mx (R.S.-V.); esantellano@uach.mx (E.S.-E.) \\ 2 Departamento de Investigación y Posgrado, Facultad de Ciencias Químicas, Universidad Autónoma de \\ Chihuahua, Circuito Universitario s/n Campus Universitario 2, Chihuahua 31125, CI, Mexico; \\ mruizg@uach.mx \\ * Correspondence: amchavez@uach.mx; Tel.: +52-614-239-8948
}

Citation: Flores-Mancha, M.A.; Ruíz-Gutiérrez, M.G.; Sánchez-Vega, R.; Santellano-Estrada, E.;

Chávez-Martínez, A. Effect of Encapsulated Beet Extracts (Beta vulgaris) Added to Yogurt on the Physicochemical Characteristics and Antioxidant Activity. Molecules 2021, 26, 4768. https://doi.org/10.3390/ molecules 26164768

Academic Editors: Severina Pacifico and Simona Piccolella

Received: 23 June 2021

Accepted: 31 July 2021

Published: 6 August 2021

Publisher's Note: MDPI stays neutral with regard to jurisdictional claims in published maps and institutional affiliations.

Copyright: (C) 2021 by the authors. Licensee MDPI, Basel, Switzerland. This article is an open access article distributed under the terms and conditions of the Creative Commons Attribution (CC BY) license (https:/ / creativecommons.org/licenses/by/ $4.0 /)$.

\begin{abstract}
Beet has been used as an ingredient for functional foods due to its high antioxidant activity, thanks to the betalains it contains. The effects of the addition of beet extract (liquid and lyophilized) on the physicochemical characteristics, color, antioxidant activity (AA), total betalains (TB), total polyphenols (TP), and total protein concentration (TPC) were evaluated on stirred yogurt. The treatments (T1-yogurt natural, T2-yogurt added with beet juice, T3-added extract of beet encapsulated with maltodextrin, and T4-yogurt added with extract of beet encapsulated with inulin) exhibited results with significant differences $(p<0.05)$. The highest TB content was observed in T2 (209.49 \pm 14.91$)$, followed by T3 (18.65 \pm 1.01$)$ and later T4 (12.96 \pm 0.55$)$. The highest AA was observed on T2 after 14 days (ABTS $0.819 \mathrm{mM}$ TE/100 $\mathrm{g}$ and DPPH' $0.343 \mathrm{mM} \mathrm{TE} / 100 \mathrm{~g}$ ), and the lowest was found on T1 at day 14 (ABTS 0.526 mM TE/100 $\mathrm{g}$ and DPPH' $0.094 \mathrm{mM} \mathrm{TE} / 100 \mathrm{~g}$ ). A high content of TP was observed (7.13 to $9.79 \mathrm{mg}$ GAE/g). The TPC varied between 11.38 to $12.56 \mu \mathrm{g} / \mathrm{mL}$. The addition of beet extract significantly increased AA in yogurt, betalains being the main compounds responsible for that bioactivity.
\end{abstract}

Keywords: yogurt; betalains; encapsulation; lyophilization; antioxidant activity; polyphenols

\section{Introduction}

Dairy derivatives are the main segment among functional foods, representing around $74 \%$ of all functional products [1].Yogurt is a functional dairy food that is obtained from the fermentation of milk with lactic acid bacteria (LAB); it is consumed around the world and is traditionally recognized as a healthy food due to its own characteristics [2], which can be improved by incorporating natural ingredients such as fruit extracts [3], tea [4], olive leaf extract [5], paprika juice [6], coriander and cumin seeds [7], etc. It has been reported that the high oxidative stability of yogurt is due to the peptides released during the fermentation carried out by LAB [8]. According to the latest studies, the use of various additives and fruit, in yogurt production, has a significant influence its quality $[9,10]$. Thus, the addition of natural food materials increases the nutritive value of yogurt. The fortification of yogurt using different bioactive compounds has been studied by different authors [4-7,11,12]; encapsulation by extrusion can significantly extend the stability of natural $\beta$-carotene with potential use as a functional ingredient in yogurt [13]. The addition of hibiscus flower essential oil can also be used to increase the antioxidant capacity of yogurt due to anthocyanin content [12]. Green, white and black tea can be used successfully to enhance the antioxidant properties of yogurt and provide sustained antioxidants during 
storage [4]. On the other hand, the addition of carotenoids in a fermented-maize product, similar to yogurt, can induce a cholesterol lowering effect [14].

Beet (Beta vulgaris sp.) represent the main commercial source of betalains [15-17], in addition to containing polyphenols, both being powerful antioxidants. In recent decades, the functional properties that these compounds confer on health have been studied, among which their antioxidant (AA), antidiabetic, anti-inflammatory and anticancer activity stand out [18-25]. Beet extract (betanin) is an approved color under the code 73.40 by the US Food and Drug Administration $[17,26]$ and by the European Union designated with the number E162 [22,27]. Betalains and polyphenols are unstable in the presence of light [28], high temperatures [29], alkaline $\mathrm{pH}$ [30,31], enzymatic activity [32], and presence of oxygen and/or metals [33,34]. Due to their low stability, their use in food has been restricted [3,35-42]. However, it has been shown that the encapsulation of betalains and polyphenols in different edible matrices (maltodextrin and inulin) can increase the stability of these compounds and therefore retain their antioxidant and anti-radical activities [21,43-49]. Therefore, the objective of this work was to evaluate the effect of adding beet extract (Beta vulgaris sp.) encapsulated with different carrier agents on the physicochemical characteristics, color, betalain and polyphenol content, and antioxidant capacity of yogurt during shelf life. The treatments were as follows: T1-natural yogurt as control, T2-yogurt added with beet juice, T3-added extract of beet encapsulated with maltodextrin, and T4-yogurt added with extract of beet encapsulated with inulin.

\section{Results and Discussion}

\subsection{Physicochemical Analysis}

The treatments added with encapsulated beet extract (T3 and T4) presented higher protein content ( $4.88 \pm 0.22$ and $4.84 \pm 0.48$, respectively), showing a significant difference $(p<0.05)$, compared to T1 $(3.87 \pm 0.31)$ and with T2 $(3.88 \pm 0.36)(p<0.05)$. Regarding the percentage of fat, treatments T3 $(5.49 \pm 0.81)$ and T4 $(5.36 \pm 0.32)$ had a higher content in contrast to $\mathrm{T} 1(5.09 \pm 0.45)$ and $\mathrm{T} 2(5.02 \pm 0.86)$ (Table 1$)$, although in this determination, there was no significant difference $(p>0.05)$ between the treatments. Other studies indicate that yogurts added with rubas (Ullucus tuberosus) concentrate, curuba (Passiflora mollissima Bailey) extract, chocolate, and oats also showed a significant increase in protein and fat content [50-53]. The moisture percentage showed a significant difference $(p<0.05)$ in the four treatments, this behavior could be attributed to the fact that the beet extracts were in different forms (juice or powders), since in treatments 3 and 4 added with powders, the moisture content was lower $(78.10 \pm 0.17$ and $78.60 \pm 0.33)$ than in $\mathrm{T} 1(78.94 \pm 0.15)$, likewise, the moisture percentage of T2 was higher (79.92 \pm 0.12$)$ than T1. Regarding the percentage of ash, there was no significant difference $(p>0.05)$ between the treatments.

Table 1. Physicochemical analysis of yogurt added with beet extracts (Beta vulgaris sp.).

\begin{tabular}{ccccc}
\hline Treatment & \% Fat & \% Protein & \% Moisture & \% Ashes \\
\hline T1 & $5.09 \pm 0.45^{\mathrm{a}}$ & $3.87 \pm 0.31^{\mathrm{b}}$ & $78.94 \pm 0.15^{\mathrm{b}}$ & $0.18 \pm 0.01^{\mathrm{a}}$ \\
T2 & $5.02 \pm 0.86^{\mathrm{a}}$ & $3.88 \pm 0.36^{\mathrm{b}}$ & $79.92 \pm 0.12^{\mathrm{a}}$ & $0.18 \pm 0.01^{\mathrm{a}}$ \\
T3 & $5.49 \pm 0.81^{\mathrm{a}}$ & $4.88 \pm 0.22^{\mathrm{a}}$ & $78.10 \pm 0.17^{\mathrm{d}}$ & $0.18 \pm 0.02^{\mathrm{a}}$ \\
T4 & $5.36 \pm 0.32^{\mathrm{a}}$ & $4.84 \pm 0.48^{\mathrm{a}}$ & $78.60 \pm 0.33^{\mathrm{c}}$ & $0.19 \pm 0.02^{\mathrm{a}}$ \\
\hline
\end{tabular}

T1 = Natural yogurt $(\mathrm{Y}), \mathrm{T} 2=\mathrm{Y}$ added with beet juice, $\mathrm{T} 3=\mathrm{Y}$ added with encapsulated extract with Maltodextrin and $\mathrm{T} 4=\mathrm{Y}$ added with encapsulated extract with Inulin. $\mathrm{a}, \mathrm{b}, \mathrm{c}, \mathrm{d}$ Values with different superscript between rows indicate significant statistical difference between treatments $(p<0.05)$.

\section{2. $p H$ and Syneresis (SYN)}

All treatments presented a decrease in $\mathrm{pH}$ over time $(p<0.05)$. These values were $4.13 \pm 0.052$ on day $1,4.04 \pm 0.030$ on day 7 , and $3.95 \pm 0.010$ on day 14 (Figure 1), and that decrease in $\mathrm{pH}$ could be attributed to the microbial activity of the lactic acid bacteria present in yogurt $[52,54]$. The degree of SYN varied from 18.01 to $35.32 \%$, presenting significant differences $(p<0.05)$ between treatments and days of storage (Figure 2). 


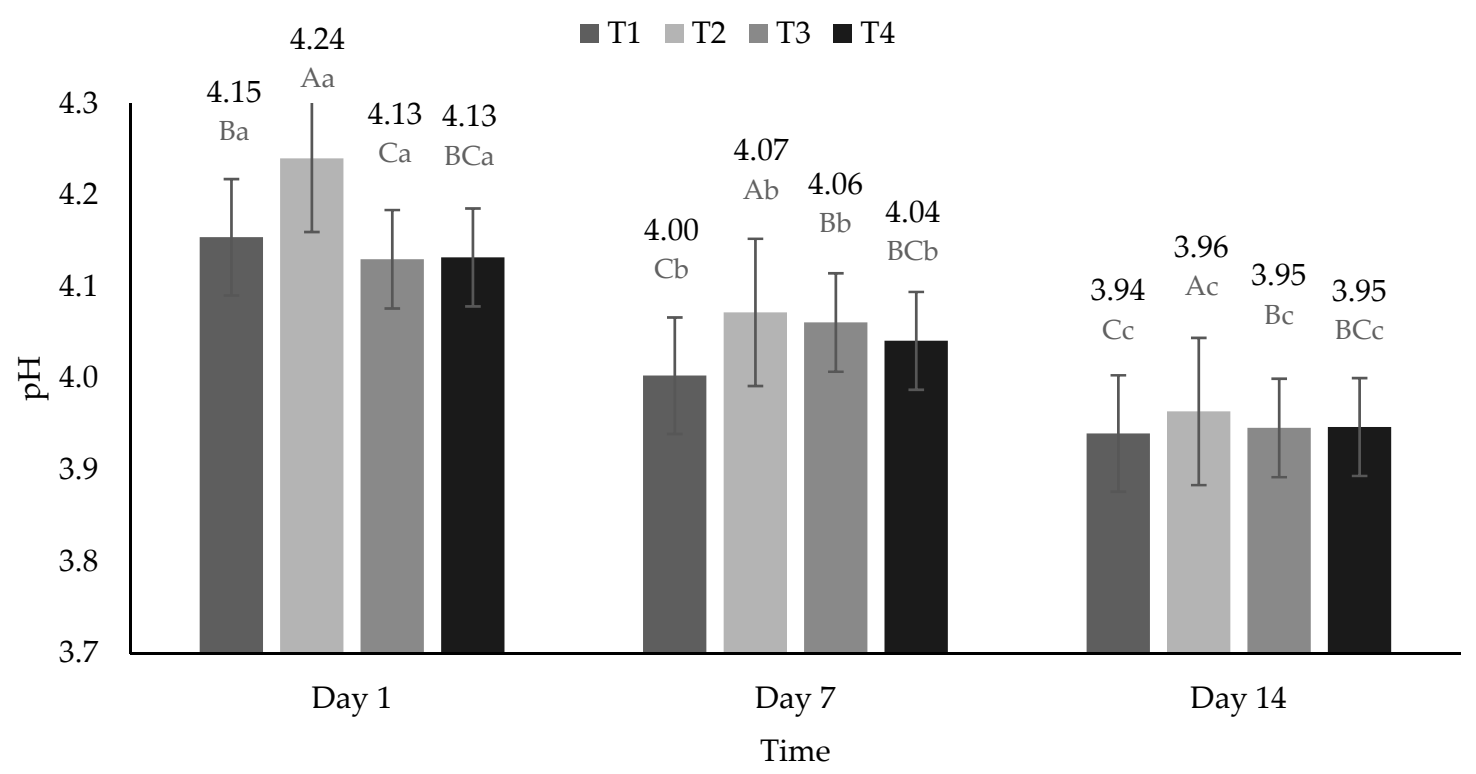

Figure 1. Hydrogen potential $(\mathrm{pH})$ of yogurt added with beet extracts. $\mathrm{T} 1=$ Natural yogurt $(\mathrm{Y}), \mathrm{T} 2=\mathrm{Y}$ added with beet juice, $\mathrm{T} 3=\mathrm{Y}$ added with extract encapsulated with Maltodextrin, and T4 $=\mathrm{Y}$ added with extract encapsulated with Inulin. $\mathrm{A}, \mathrm{B}, \mathrm{C}$ Values with different superscript indicate significant statistical difference between treatments $(p<0.05)$. ${ }^{\mathrm{a}, \mathrm{b}, \mathrm{c}}$ Values with a different superscript indicate a statistically significant difference over time $(p<0.05)$.

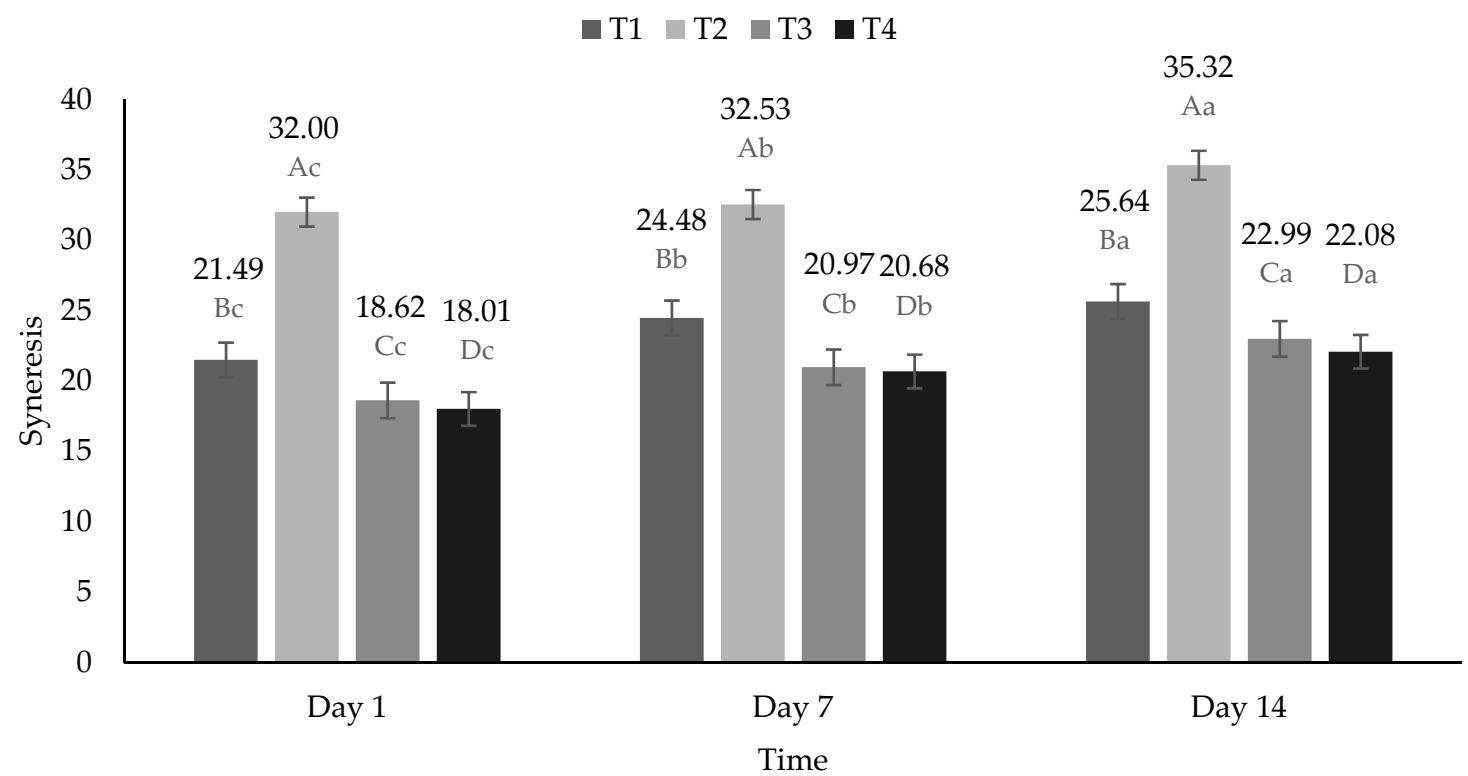

Figure 2. Percentage of syneresis of yogurt added with beet extracts. $\mathrm{T} 1=$ Natural yogurt $(\mathrm{Y}), \mathrm{T} 2=\mathrm{Y}$ added with beet juice, $\mathrm{T} 3=\mathrm{Y}$ added with extract encapsulated with Maltodextrin, and $\mathrm{T} 4=\mathrm{Y}$ added with extract encapsulated with Inulin. $\mathrm{A}, \mathrm{B}, \mathrm{C}, \mathrm{D}$ Values with different superscript indicate significant statistical difference between treatments $(p<0.05)$. ${ }^{a, b, c}$ Values with different superscript indicate statistical difference significant over time $(p<0.05)$.

These differences between treatments could be attributed to the fact that the components of the powders, specifically maltodextrin and inulin, favored water retention, because they contribute to the mesh effect in the three-dimensional network of the gel formed in the yogurt [55]. In addition, syneresis increased in all treatments during storage, possibly due to the loss of stability of the yogurt components [56]. This behavior is also due to the decrease in $\mathrm{pH}$ during storage, since it can have a contraction effect in the casein micelle matrix causing greater elimination of whey [57]. 


\subsection{Color}

The values of the color parameters $L^{*}, a^{*}$ and $b^{*}$ can be observed in Table 2. The values of $\mathrm{L}^{*}$ decreased significantly for $\mathrm{T} 1, \mathrm{~T} 3$, and $\mathrm{T} 4$, although this value increased in $\mathrm{T} 2$ from 43.70 at day 1 to 50.88 at day $14(p<0.05)$. In relation to the parameter a* (Table 2), this was reduced in T3 after storage, and this trend was reported [58] in microcapsules of beets using $\mathrm{M}$ as a vehicle (day 0 to $\mathrm{a}^{*}=8.39$, day 7 to $\mathrm{a}^{*}=1.71$ ); however, the $\mathrm{a}^{*}$ values for T1, T2, and T4 showed an increase over time $(p<0.05)$. In general, the $\mathrm{b}^{*}$ values also showed an increase over time $(p<0.05)$. The degradation of BC leads to the formation of compounds with a yellow color and, this is reflected in the increase in the $b^{*}$ parameter [38]. Color saturation (Chroma) and hue (Hue angle) indicated differences $(p<0.05)$ between treatments and over time; however, treatments added with beet powder (T3 and T4) did not show differences $(p>0.05)$. The color change $(\Delta \mathrm{E})$ between treatments and days was also different $(p<0.05)$.

Table 2. Color values $\mathrm{L}^{*}, \mathrm{a}^{*}, \mathrm{~b}^{*}, \mathrm{C}^{*}, \mathrm{~h}^{*}$ and $\Delta \mathrm{E}$ of yogurt added with liquid extract and lyophilized of beet (Beta vulgaris sp.).

\begin{tabular}{cccccc}
\hline Parameter & Day & T1 & T2 & T3 & T4 \\
\hline $\mathrm{L}^{*}$ & 1 & $96.354 \pm 2.543^{\mathrm{Aa}}$ & $43.700 \pm 1.376^{\mathrm{Db}}$ & $79.330 \pm 1.441^{\mathrm{Cb}}$ & $83.678 \pm 0.659^{\mathrm{Ba}}$ \\
& 7 & $88.170 \pm 1.294^{\mathrm{Ab}}$ & $41.780 \pm 1.828^{\mathrm{Dc}}$ & $82.079 \pm 2.189^{\mathrm{Ca}}$ & $80.719 \pm 0.503 \mathrm{Bc}$ \\
& 14 & $87.528 \pm 2.448^{\mathrm{Ac}}$ & $50.884 \pm 1.742^{\mathrm{Da}}$ & $76.927 \pm 2.739^{\mathrm{Cc}}$ & $82.225 \pm 1.033^{\mathrm{Bb}}$ \\
$\mathrm{a}^{*}$ & 1 & $-3.522 \pm 0.124^{\mathrm{Cb}}$ & $32.763 \pm 1.729^{\mathrm{Ab}}$ & $22.705 \pm 0.998^{\mathrm{Ba}}$ & $21.076 \pm 0.688^{\mathrm{Bb}}$ \\
& 7 & $-3.272 \pm 0.232^{\mathrm{Ca}}$ & $30.701 \pm 1.254^{\mathrm{Ab}}$ & $21.581 \pm 0.601^{\mathrm{Bb}}$ & $22.822 \pm 0.051^{\mathrm{Ba}}$ \\
& 14 & $-3.266 \pm 0.106^{\mathrm{Ca}}$ & $39.563 \pm 3.047^{\mathrm{Aa}}$ & $22.137 \pm 0.816^{\mathrm{Bb}}$ & $22.118 \pm 0.732^{\mathrm{Ba}}$ \\
$\mathrm{b}^{*}$ & 1 & $8.612 \pm 0.303^{\mathrm{Ab}}$ & $2.174 \pm 0.209^{\mathrm{Bb}}$ & $0.617 \pm 0.097^{\mathrm{Db}}$ & $1.574 \pm 0.380^{\mathrm{Ca}}$ \\
& 7 & $9.533 \pm 0.281^{\mathrm{Aa}}$ & $3.254 \pm 0.077^{\mathrm{Ba}}$ & $1.344 \pm 0.248^{\mathrm{Da}}$ & $0.696 \pm 0.024^{\mathrm{Cb}}$ \\
& 14 & $9.037 \pm 0.132^{\mathrm{Aa}}$ & $3.527 \pm 0.414^{\mathrm{Ba}}$ & $1.182 \pm 0.117^{\mathrm{Da}}$ & $1.169 \pm 0.127^{\mathrm{Ca}}$ \\
$\mathrm{C}^{*}$ & 1 & $9.305 \pm 0.278^{\mathrm{Cb}}$ & $32.835 \pm 1.735^{\mathrm{Ab}}$ & $22.713 \pm 0.998^{\mathrm{Ba}}$ & $21.135 \pm 0.673^{\mathrm{Bb}}$ \\
& 7 & $10.078 \pm 0.314^{\mathrm{Ca}}$ & $30.873 \pm 1.241^{\mathrm{Ab}}$ & $21.623 \pm 0.595^{\mathrm{Bb}}$ & $22.833 \pm 0.503^{\mathrm{Ba}}$ \\
& 14 & $9.609 \pm 0.134^{\mathrm{Cb}}$ & $39.720 \pm 3.067^{\mathrm{Aa}}$ & $22.169 \pm 0.819^{\mathrm{Bb}}$ & $22.149 \pm 0.732^{\mathrm{Ba}}$ \\
$\mathrm{h}^{*}$ & 1 & $2.445 \pm 0.134^{\mathrm{Cc}}$ & $0.066 \pm 0.005^{\mathrm{Ac}}$ & $0.027 \pm 0.004^{\mathrm{Bc}}$ & $0.075 \pm 0.019^{\mathrm{Ba}}$ \\
& 7 & $2.913 \pm 0.168^{\mathrm{Ca}}$ & $0.106 \pm 0.006^{\mathrm{Aa}}$ & $0.062 \pm 0.012^{\mathrm{Ba}}$ & $0.030 \pm 0.002^{\mathrm{Bc}}$ \\
& 14 & $2.767 \pm 0.091^{\mathrm{Cb}}$ & $0.089 \pm 0.006^{\mathrm{Ab}}$ & $0.053 \pm 0.005^{\mathrm{Bb}}$ & $0.053 \pm 0.006^{\mathrm{Bb}}$ \\
& 1 & - & $64.268 \pm 1.584^{\mathrm{Aa}}$ & $32.273 \pm 1.803^{\mathrm{Ba}}$ & $28.553 \pm 1.059^{\mathrm{Ca}}$ \\
& 7 & - & $57.841 \pm 1.971^{\mathrm{Ab}}$ & $26.867 \pm 0.739^{\mathrm{Bb}}$ & $28.539 \pm 0.690^{\mathrm{Ca}}$ \\
& 14 & - & $56.635 \pm 2.469^{\mathrm{Ab}}$ & $28.626 \pm 1.782^{\mathrm{Bb}}$ & $27.099 \pm 1.012^{\mathrm{Cb}}$ \\
\hline
\end{tabular}

$\mathrm{T} 1=$ Natural yogurt $(\mathrm{Y}), \mathrm{T} 2=\mathrm{Y}$ added with beet juice, $\mathrm{T} 3=\mathrm{Y}$ added with extract encapsulated with Maltodextrin and $\mathrm{T} 4=\mathrm{Y}$ added with extract encapsulated with Inulin. $L^{*}=$ luminosity, $a^{*}=$ green $(-)$ and red $(+), b^{*}=$ blue $(-)$ and yellow $(+), C^{*}=$ chroma (color saturation), $\mathrm{h}^{*}=$ Hue angle (hue), and $\Delta \mathrm{E}=$ color difference. $\mathrm{A}, \mathrm{B}, \mathrm{C}, \mathrm{D}$ Values in columns with different superscript indicate significant statistical difference between treatments $(p<0.05)$. ${ }^{a}, b, c$ Values in rows with different superscript indicate significant statistical difference over time $(p<0.05)$.

\subsection{Antioxidant Activity ( $A A)$}

Statistically significant differences $(p<0.05)$ were found for the AA variable between the treatments $(p<0.05)$ in ABTS (Figure 3$)$ and DPPH' (Figure 4). The highest AA was observed on T2 after 14 days (ABTS' $0.819 \mathrm{mM} \mathrm{TE} / 100 \mathrm{~g}$ and DPPH' $0.343 \mathrm{mM} \mathrm{TE} / 100 \mathrm{~g}$ ), and the lowest AA was found on T1 at day 14 (ABTS $0.526 \mathrm{mM} \mathrm{TE} / 100 \mathrm{~g}$ and DPPH' $0.094 \mathrm{mM} \mathrm{TE} / 100 \mathrm{~g})$. Among the treatments added with encapsulated extract, the highest AA was found in T3 on day 1 (ABTS $0.667 \mathrm{mM} \mathrm{TE} / 100 \mathrm{~g}$ and DPPH' $0.197 \mathrm{mM}$ TE/100 g). On the other hand, T4 presented higher AA on day 7 (ABTS $0.644 \mathrm{mM} \mathrm{TE} / 100 \mathrm{~g}$ and $\left.\mathrm{DPPH}^{\cdot} 0.145 \mathrm{mM} \mathrm{TE} / 100 \mathrm{~g}\right)$; it is important to highlight that for this treatment, the AA was higher on day 14 (ABTS $0.613 \mathrm{mM} \mathrm{TE} / 100 \mathrm{~g}$ and $\mathrm{DPPH}^{*} 0.136 \mathrm{mM} \mathrm{TE} / 100 \mathrm{~g}$ ) even

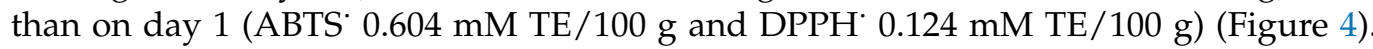
Likewise, a decrease on AA was reported previously, followed by a 10 day stability period and an increase in AA by day 14 [59]. This behavior could be due to compounds with high antioxidant activity that were formed or released during storage due to the adsorption of water by encapsulation or to the interaction of some components in the stored sample with oxygen or other components of the sample [60]. In addition, it has been reported that a 
longer storage time and a greater water activity produce greater antioxidant activity to extinguish radicals $[59,61]$.

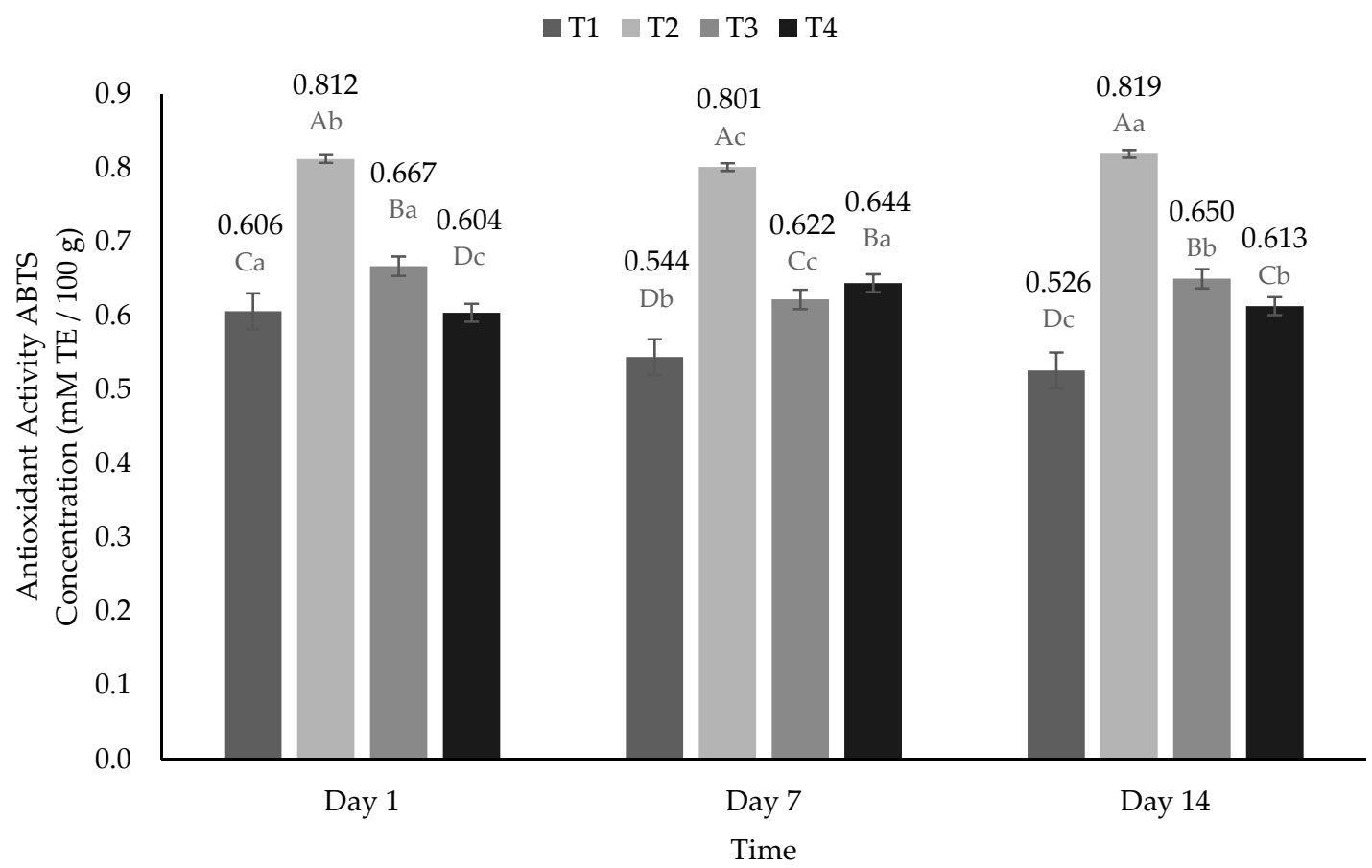

Figure 3. Antioxidant activity (ABTS method) of yogurt added with beet extract. $\mathrm{T} 1=$ Natural yogurt $(\mathrm{Y}), \mathrm{T} 2=\mathrm{Y}$ added with beet juice, T3 $=\mathrm{Y}$ added with extract encapsulated with Maltodextrin, and T4 = Y added with extract encapsulated with Inulin. A,B,C,D Values with different superscript indicate significant statistical difference between treatments $(p<0.05)$. $a, b, c$ Values with a different superscript indicate significant statistical difference over time $(p<0.05)$.

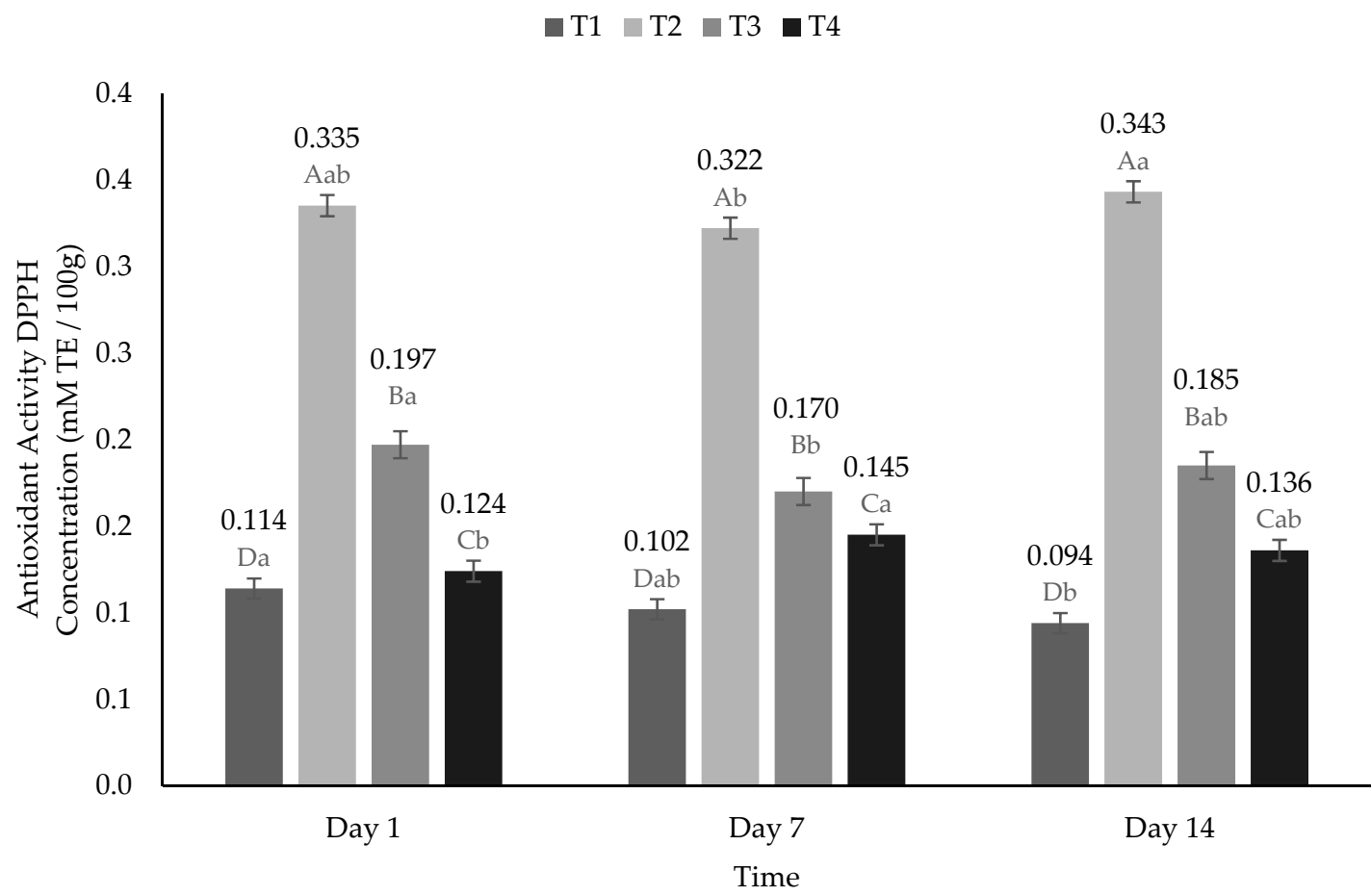

Figure 4. Antioxidant activity ( $\mathrm{DPPH}$ method) of yogurt added with beet extract. $\mathrm{T} 1=$ Natural yogurt $(\mathrm{Y}), \mathrm{T} 2=\mathrm{Y}$ added with beet juice, T3 $=$ Y added with extract encapsulated with Maltodextrin, and T4 = Y added with extract encapsulated with Inulin. A,B,C,D Values with different superscript indicate significant statistical difference between treatments $(p<0.05)$. $\mathrm{a}, \mathrm{b}$ Values with a different superscript indicate significant statistical difference over time $(p<0.05)$. 


\subsection{Total Polyphenols (TP)}

A high content of TP was observed from 7.13 to $9.79 \mathrm{mg}$ of GAE/g, (Figure 5) referring to that reported previously $4.88 \mathrm{mg}$ of GAE/g [58]. In cactus pear (Opuntia ficus indica) powders values of $14.67 \mathrm{mg}$ of GAE/g have been reported [62]. The concentration of TP showed a behavior reported previously [48], where report recoveries and polyphenol formation of more than $100 \%$ with respect to the initial time, as a consequence of the hydrolysis of the beet polyphenol conjugates during storage [48]. Storage with high water activity facilitates oxidation reactions, causing phenolic compounds to react with oxygen and produce an enriched medium that has strong radical elimination and reduction properties [59]; it is worth mentioning that these studies were carried out only on powders.

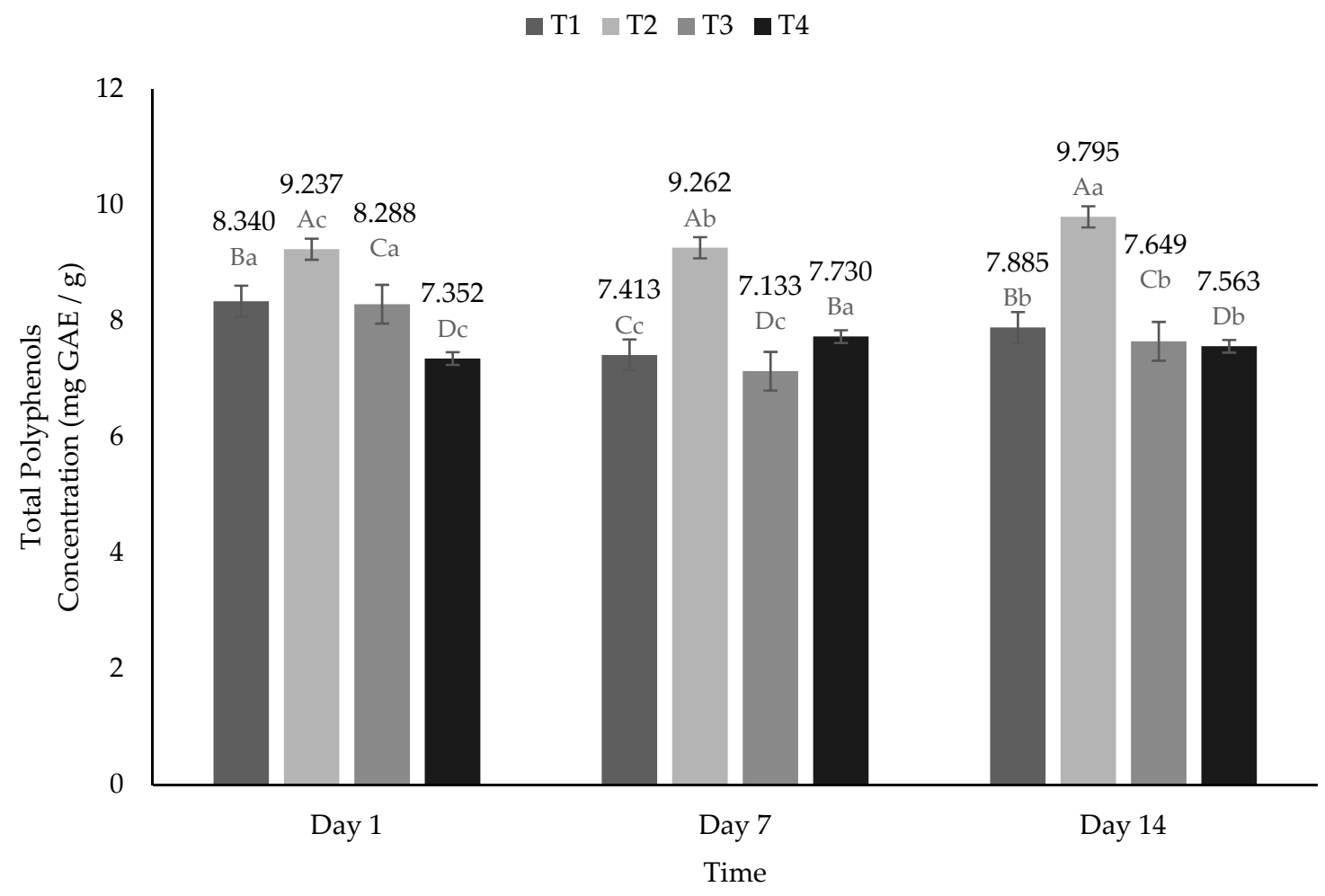

Figure 5. Total polyphenol content of yogurt added with beet extract. $\mathrm{T} 1=$ Natural yogurt $(\mathrm{Y}), \mathrm{T} 2=\mathrm{Y}$ added with beet juice, $\mathrm{T} 3=\mathrm{Y}$ added with extract encapsulated with Maltodextrin, and $\mathrm{T} 4=\mathrm{Y}$ added with extract encapsulated with Inulin. A,B,C,D Values with different superscript indicate significant statistical difference between treatments $(p<0.05){ }^{\mathrm{a}, \mathrm{b}, \mathrm{c}}$ Values with a different superscript indicate significant statistical difference over time $(p<0.05)$.

\subsection{Total Betalains (TB)}

Several investigations have been carried out on the use of encapsulating agents to prevent the degradation of betalains $[35,58,63,64]$; however, the most of the stability studies were conducted on powder samples. In the present study, the powder was added to a non-Newtonian fluid. The stability of the extracts was evaluated in the yogurts in terms of TB content (Figure 6), during 14 days of storage at $4{ }^{\circ} \mathrm{C}$ and in absence of light. The highest pigment content was observed in T2 after 14 days $(243.20 \mathrm{mg} / 100 \mathrm{~g})$; statistically significant differences $(p<0.05)$ in TB content were observed after $7(191.65 \mathrm{mg} / 100 \mathrm{~g})$ and 14 days of storage compared to its content on day $1(209.40 \mathrm{mg} / 100 \mathrm{~g})$. The TB content increased with the fermentation time, and that event could be due to acid hydrolysis and the bioconversion of condensed phenols $[29,65]$. In addition, during fermentation, microbial activity caused an intense release of betalains responsible for the increase in TB content [61]. Of the treatments added with encapsulated extract (T3 and T4), the highest TB content was found in T3 on day $1(18,652 \mathrm{mg} / 100 \mathrm{~g})$, and the highest TB content for T4 was on day $7(18,024 \mathrm{mg} / 100 \mathrm{~g})$. However, while T3 showed a decrease in TB on day 
$7(10.24 \mathrm{mg} / 100 \mathrm{~g})$ and subsequently an increase on day $14(15.06 \mathrm{mg} / 100 \mathrm{~g}), \mathrm{T} 4 \mathrm{had}$ an increase in TB on day $7(18.02 \mathrm{mg} / 100 \mathrm{~g})$ and on day 14 a decrease $(15.26 \mathrm{mg} / 100 \mathrm{~g})$. However, it is important to note that on day 14 the quantification of TB in T4 was higher, even than on day $1(12.96 \mathrm{mg} / 100 \mathrm{~g})$ (Figure 6).

$\square \mathrm{T} 2 \square \mathrm{T} 3 \square \mathrm{T} 4$

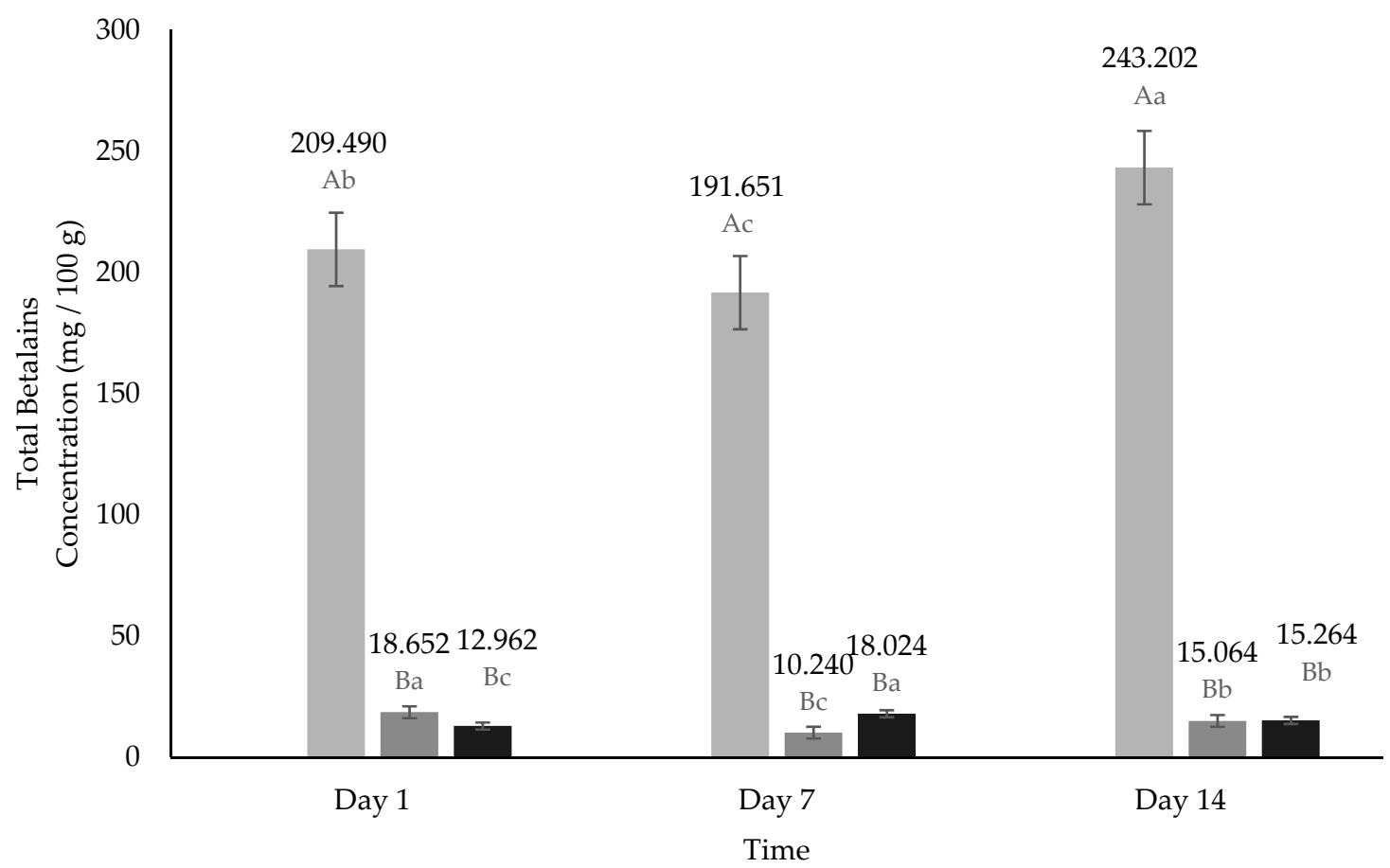

Figure 6. Total betalain content of yogurt added with beet extract. $\mathrm{T} 2=\mathrm{Y}$ added with beet juice, $\mathrm{T} 3=\mathrm{Y}$ added with extract encapsulated with Maltodextrin, and T4 $=\mathrm{Y}$ added with extract encapsulated with Inulin. A,B Values with different superscript indicate significant statistical difference between treatments $(p<0.05) .{ }^{\mathrm{a}, \mathrm{b}, \mathrm{c}}$ Values with a different superscript indicate significant statistical difference over time $(p<0.05)$.

Encapsulation with maltodextrin was effective in stabilizing betalains after 14 days of storage [66]. Unlike what was reported by Omae et al. [46], in this study, the addition of inulin did increase the stability of BC during storage, and a linear relationship was not observed from the graphs of $\mathrm{TB}$ content versus time. According to previous studies $[28,29,67,68]$, the degradation of $B C$ is the result of a hydrolysis reaction that produces cyclo-DOPA-D-glucoside (CDG) and $A B$; this degradation reaction is reversible, and involves a condensation of the Schiff's base of the CDG amine with the aldehyde of betalamic acid (BA) [69]. On the other hand, the degradation of betalamic pigments derived from beets was reported $[46,58,59,63]$.

Beets have been reported to have higher levels of betacianins (BC) than betaxanthins (BX) [63,70-72]. According to the above, in this investigation, a higher content of BC was found compared to BX. The contents of BC (6.22 to $11.809 \mathrm{mg} / 100 \mathrm{~g})$ and BX (4.01 to $6.85 \mathrm{mg} / 100 \mathrm{~g}$ ) (Figures 7 and 8) in the treatments added with encapsulated beet extract (T3 and T4) in this study were lower than those reported by Janiszewska [63] and higher than those reported by Ravichandran et al. [72] (118.0 mg/100 g and $3.5 \mathrm{mg} / 100 \mathrm{~g}$, respectively). 


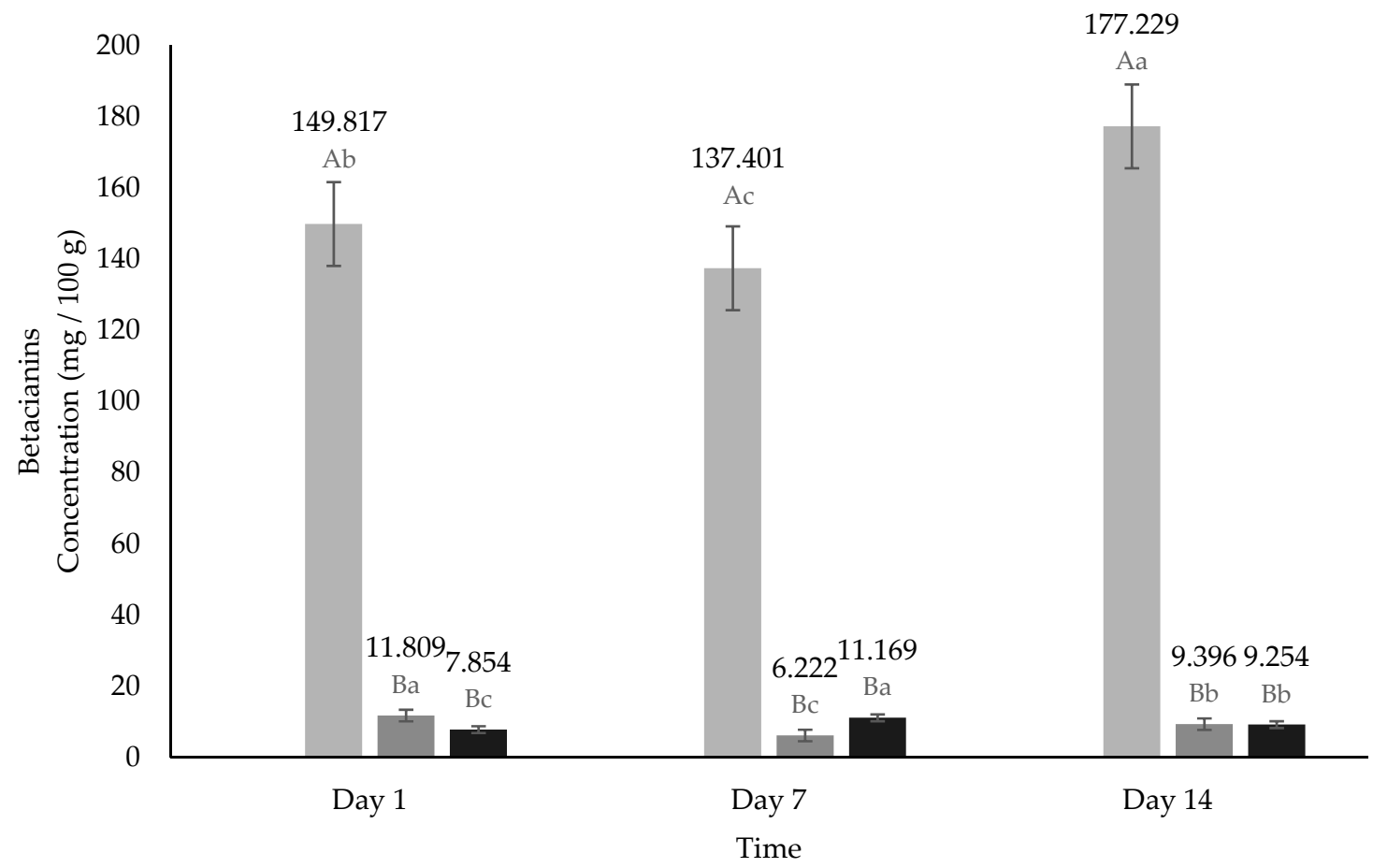

Figure 7. Betacyanins content of yogurt added with beet extract. $\mathrm{T} 2=\mathrm{Y}$ added with beet juice, $\mathrm{T} 3=\mathrm{Y}$ added with extract encapsulated with Maltodextrin, and $\mathrm{T} 4=\mathrm{Y}$ added with extract encapsulated with Inulin. A,B Values with different superscript indicate significant statistical difference between treatments $(p<0.05)$. ${ }^{\mathrm{a}, \mathrm{b}, \mathrm{c}}$ Values with a different superscript indicate significant statistical difference over time $(p<0.05)$.

\section{$\square \mathrm{T} 2 \square \mathrm{T} 3 \square \mathrm{T} 4$}

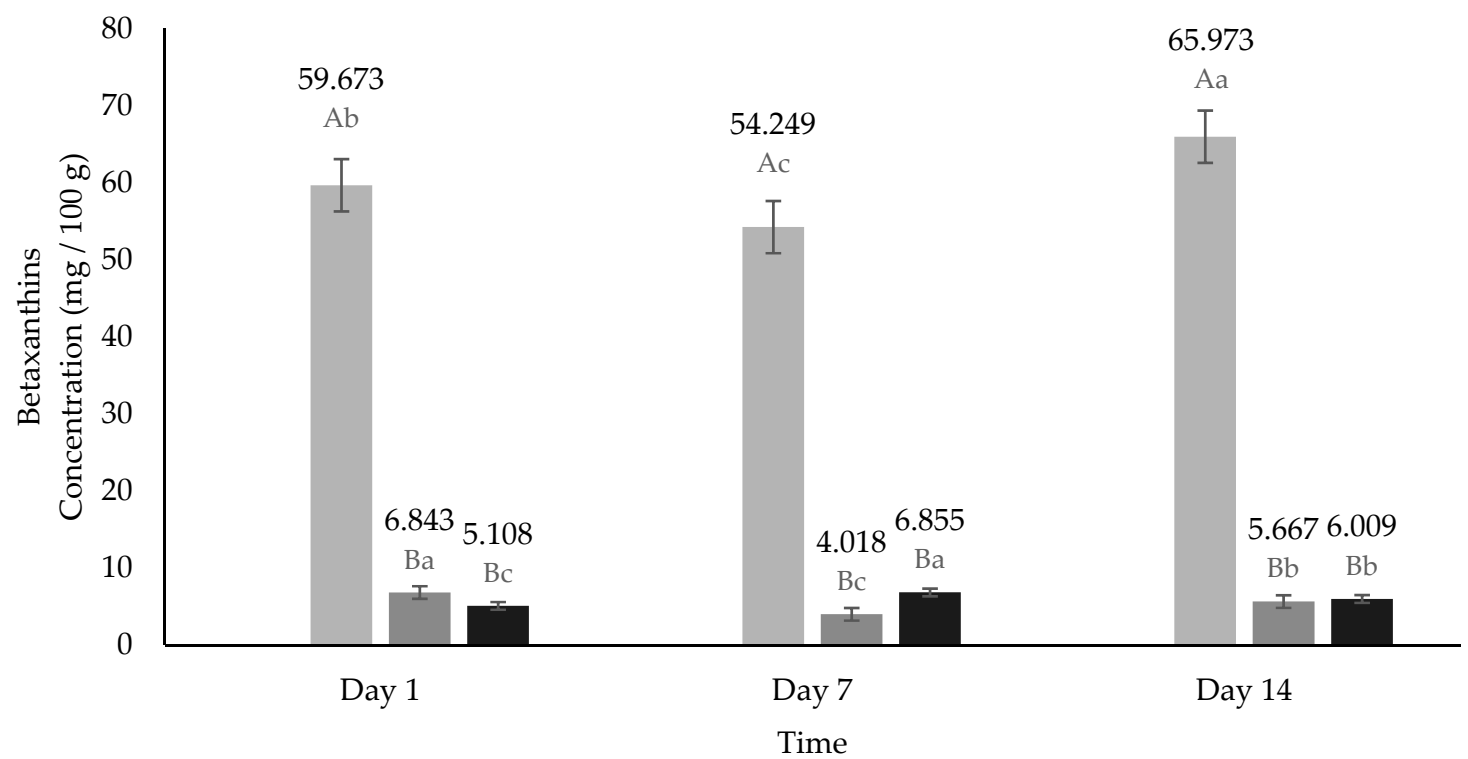

Figure 8. Betaxanthins content of yogurt added with beet extract. $\mathrm{T} 2=\mathrm{Y}$ added with beet juice, $\mathrm{T} 3=\mathrm{Y}$ added with extract encapsulated with Maltodextrin, and $\mathrm{T} 4=\mathrm{Y}$ added with extract encapsulated with Inulin. ${ }^{\mathrm{A}, \mathrm{B}}$ Values with different superscript indicate significant statistical difference between treatments $(p<0.05)$. ${ }^{\mathrm{a}, \mathrm{b}, \mathrm{c}}$ Values with a different superscript indicate significant statistical difference over time $(p<0.05)$. 


\subsection{Total Protein Concentration (TPC)}

The TPC (Figure 9) ranged from 11.385 to $12.568 \mu \mathrm{g} / \mathrm{mL}$. However, they had a statistically significant difference $(p<0.05)$ between treatments and over time. This behavior is probably due to the extracellular proteins secreted by bacteria during the fermentation time [73]. Furthermore, the increase in the total content of betalains has a positive correlation regarding the total concentration of proteins, due to the fact that they are nitrogenous compounds [74].

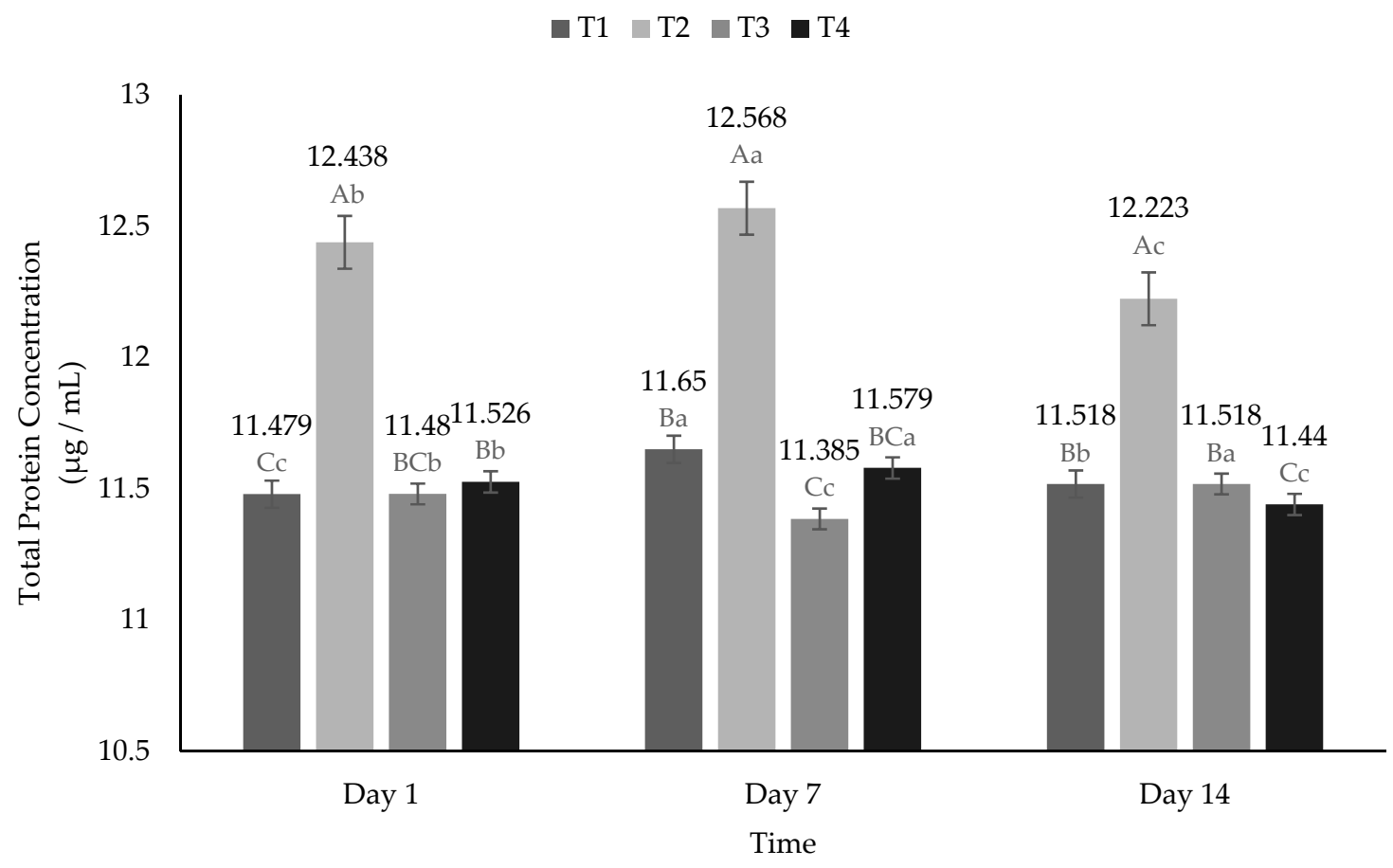

Figure 9. Total protein concentration of yogurt added with beet extract. $\mathrm{T} 1=$ Natural yogurt $(\mathrm{Y}), \mathrm{T} 2=\mathrm{Y}$ added with beet juice, $\mathrm{T} 3=\mathrm{Y}$ added with extract encapsulated with Maltodextrin, and T4 $=\mathrm{Y}$ added with extract encapsulated with Inulin. $\mathrm{A}, \mathrm{B}, \mathrm{C}$ Values with different superscript indicate significant statistical difference between treatments $(p<0.05){ }^{\mathrm{a}, \mathrm{b}, \mathrm{c}}$ Values with a different superscript indicate significant statistical difference over time $(p<0.05)$.

\subsection{Correlation between Variables}

Table 3 shows the correlation coefficient (r) and level of significance between the response variables of the yogurts. A strong negative correlation $(\mathrm{r}=-0.9410, p<0.0001)$ was found between $L^{*}$ and TB and a positive correlation $(r=0.7054, p<0.0001)$ between the value of $\mathrm{a}^{*}$ and TB. This indicates that the higher the TB content, the lower the luminosity and the higher the concentration of red color. These correlations have already been reported in prickly pear pulp micro particles $[48,75,76]$ and in prickly pear pulp coloring powders [44]. Like Pitalua et al. [59], observed a strong positive correlation $(\mathrm{r}=0.8615$, $p<0.0001$ ) between TP and TB. It is important to highlight that betalains are the main polyphenols present in beets [58]; therefore, a positive association between both variables was expected. In addition, positive correlations were obtained $(\mathrm{r}=0.9994, p<0.0001)$, $(\mathrm{r}=0.9960, p<0.0001)$ between TB and BC and between TB and BX, respectively. On the other hand, a high positive correlation $(\mathrm{r}=0.7946, p<0.0001)$ was found between TB and AA, which could be due to the presence of betalamic acid, since it acts as an antioxidant agent. However, if the acid molecule does not have hydroxyl groups, betalamic acid does not have antioxidant capacity [64]. Likewise, a positive correlation was found (ABTS $r=0.8263$ and DPPH $r=0.8002, p<0.0001$ ) between AA and TP. The increase in AA during storage can occur because in these periods, new phenolic compounds capable of extinguishing radicals are released or formed [77]. A positive correlation was found between TPC and AA (ABTS' $r=0.8022$ and DPPH' $r=0.8126, p<0.0001)$ and TP $(r=0.7917, p<0.0001)$ 
and TB $(\mathrm{r}=0.8822, p<0.0001)$. These correlations could be to compounds with high AA that were formed or released during storage, thanks to the adsorption of water [60], and it can be observed despite the presence of betalains [64]. Storage with high water activity facilitates hydrolysis, causing phenolic compounds to react with oxygen and produce an enriched medium that has strong radical elimination and reduction properties $[65,73]$.

Table 3. Correlation between the response variables of yogurt added with liquid extract and freeze-dried beet extracts (Beta vulgaris sp.).

\begin{tabular}{|c|c|c|c|c|c|c|c|c|c|c|c|}
\hline & DPPH' & TP & TB & BC & BX & TPC & $\mathbf{L}^{*}$ & $a^{*}$ & $\mathbf{b}^{*}$ & $\mathrm{pH}$ & SYN \\
\hline ABTS & 0.9652 & 0.8263 & 0.9281 & 0.9231 & 0.9361 & 0.8022 & -0.9306 & 0.8322 & -0.4192 & 0.3101 & 0.7143 \\
\hline$p$-value & $<0.0001$ & $<0.0001$ & $<0.0001$ & $<0.0001$ & $<0.0001$ & $<0.0001$ & $<0.0001$ & $<0.0001$ & $<0.0001$ & $<0.0001$ & $<0.0001$ \\
\hline DPPH' & & 0.8002 & 0.9395 & 0.9355 & 0.9447 & 0.8128 & -0.9463 & 0.8017 & -0.3518 & 0.2469 & 0.7660 \\
\hline$p$-value & & $<0.0001$ & $<0.0001$ & $<0.0001$ & $<0.0001$ & $<0.0001$ & $<0.0001$ & $<0.0001$ & $<0.0001$ & $<0.0001$ & $<0.0001$ \\
\hline $\mathrm{TP}$ & & & 0.8615 & 0.8621 & 0.8552 & 0.7917 & -0.7921 & 0.4929 & 0.0126 & 0.2085 & 0.7890 \\
\hline$p$-value & & & $<0.0001$ & $<0.0001$ & $<0.0001$ & $<0.0001$ & $<0.0001$ & $<0.0001$ & 0.8217 & 0.0002 & $<0.0001$ \\
\hline TB & & & & 0.9994 & 0.9960 & 0.8822 & -0.9410 & 0.7054 & -0.1638 & 0.2006 & 0.8773 \\
\hline$p$-value & & & & $<0.0001$ & $<0.0001$ & $<0.0001$ & $<0.0001$ & $<0.0001$ & 0.0031 & 0.0003 & $<0.0001$ \\
\hline $\mathrm{BC}$ & & & & & 0.9924 & 0.8802 & -0.9355 & 0.6979 & -0.1525 & 0.1949 & 0.8802 \\
\hline$p$-value & & & & & $<0.0001$ & $<0.0001$ & $<0.0001$ & $<0.0001$ & 0.0059 & 0.0004 & $<0.0001$ \\
\hline $\mathrm{BX}$ & & & & & & 0.8827 & -0.9502 & 0.7214 & -0.1927 & 0.2147 & 0.8645 \\
\hline$p$-value & & & & & & $<0.0001$ & $<0.0001$ & $<0.0001$ & 0.0005 & $<0.0001$ & $<0.0001$ \\
\hline $\mathrm{TPC}$ & & & & & & & -0.8939 & 0.5308 & -0.0260 & 0.2972 & 0.8480 \\
\hline$p$-value & & & & & & & $<0.0001$ & $<0.0001$ & 0.6416 & $<0.0001$ & $<0.0001$ \\
\hline $\mathrm{L}^{*}$ & & & & & & & & -0.7702 & 0.3215 & -0.2102 & -0.8032 \\
\hline$p$-value & & & & & & & & $<0.0001$ & $<0.0001$ & 0.0001 & $<0.0001$ \\
\hline$a^{*}$ & & & & & & & & & -0.7934 & 0.1319 & 0.4245 \\
\hline$p$-value & & & & & & & & & $<0.0001$ & 0.0175 & $<0.0001$ \\
\hline$b^{*}$ & & & & & & & & & & -0.1343 & 0.1679 \\
\hline$p$-value & & & & & & & & & & 0.0156 & 0.0024 \\
\hline $\mathrm{pH}$ & & & & & & & & & & & -0.0415 \\
\hline$p$-value & & & & & & & & & & & 0.4562 \\
\hline
\end{tabular}

$\mathrm{ABTS}^{\circ}$ and $\mathrm{DPPH}^{*}=$ Antioxidant activity, $\mathrm{TP}=$ Total polyphenols, $\mathrm{TB}=$ Total betalains, $\mathrm{BC}=$ Betacyanins, $\mathrm{BX}=$ Betaxanthins, $\mathrm{TPC}=$ Total protein concentration, $\mathrm{L}^{*}=$ Luminosity, $\mathrm{a}^{*}$ (tendency to red), $\mathrm{b}^{*}$ (tendency to green), and $\mathrm{SYN}=$ Syneresis. $p$-value = Level of significance of the correlation.

\section{Materials and Methods}

\subsection{Materials}

Between March and July 2018, beet, whole milk (LALA ${ }^{\circledR}$, Gomez Palacio, Dgo., Mexico), whole cream (LALA ${ }^{\circledR}$, Gomez Palacio, Dgo., Mexico), powdered milk (NIDO ${ }^{\circledR}$, Ocotlan, Mex., Mexico), table sugar, and natural yogurt (LALA ${ }^{\circledR}$, Gomez Palacio, Dgo., Mexico) were purchased in a local market in Chihuahua, Mexico. Maltodextrin (DE 10) and agave inulin were purchased from Sigma-Aldrich (St. Louis, MO, USA).

\subsection{Reagents}

All other reagents used were analytical grade. Reagents 2,2'-azino-bis (3-ethylbenzothiazoline-6-sulfonic acid) (ABTS), 2,2-diphenyl-1-picrylhydrazyl (DPPH), Trolox, ammonium salt, potassium persulfate, Folin-Ciocalteu, sodium carbonate, gallic acid, trichloroacetic acid, citrate, and phosphate standard reagent were analytical grade and obtained from Sigma-Aldrich (St. Louis, MO, USA). J. T. Baker provided high-performance liquid chromatography (HPLC)-grade methanol and HPLC-grade water (Mexico City, Mexico). A deionizer was used to obtain deionized water (Barnstead, Thermo Scientific, Waltham, MA, USA).

\subsection{Yogurt Elaboration}

To elaborate yogurts, milk was heated to $95^{\circ} \mathrm{C}$ for five minutes, then cooled to $45^{\circ} \mathrm{C}$, and then, powdered milk (8\%), cream (3\%), sugar $(3 \%)$, and the inoculum $(10 \%)$ were 
added. Next, yogurts were incubated ((Thermo Fisher Scientific, Model 3721, USA) at $42{ }^{\circ} \mathrm{C}$ for approximately $4: 30 \mathrm{~h}$, until reaching a $\mathrm{pH}$ of 4.2 . Once this acidity was reached, the yogurt was shaken and stored at $4{ }^{\circ} \mathrm{C}$ for $12 \mathrm{~h}$. Subsequently, the beet extracts (liquid or lyophilized) were added to the yogurt; a shake was made, and finally, these were stored at $4{ }^{\circ} \mathrm{C}$ for 14 days.

\subsection{Preparation of Beet Extracts}

A household extractor (Cold Press 900W, Breville, Sydney, Australia) was used to extract the juice from the beets. The encapsulating agents (Maltodextrin-M and Inulin-I) were added to the red beet juice at room temperature at an amount of $30 \mathrm{~g}$ of dry matter per $100 \mathrm{~mL}$, as described by Antigo et al. [58]. Next, the mixtures were homogenized (10 min) with a dispersion tool (Vortex-Ultra-Turrax IKA T18 basic) (S18N-19G, IKA Works Inc., Wilmington, NC, USA) and frozen for $48 \mathrm{~h}$ at $20^{\circ} \mathrm{C}$ previously to freeze-dried (4 days at $-85^{\circ} \mathrm{C}$ and 0.035 mbar pressure) in a Labconco Niro Mobile Minor Freeze-dryer. Finally, pure beet (B), beet extract encapsulated with maltodextrin (M), and beet extract encapsulated with inulin (I) were kept at $9 \pm 3{ }^{\circ} \mathrm{C}$ for further analysis. The characterization of these extracts has been reported previously [42].

\subsection{Treatments}

Four treatments with three repetitions were elaborated under a completely random statistical model. The description of the treatments was based on the addition of beet extracts (liquid or lyophilized and encapsulated). Control treatment was yogurt without the addition of beet extract (T1), yogurt added with $100 \mathrm{~mL}$ of liquid beet extract per liter (T2), yogurt added with $600 \mathrm{mg}$ of beet extract encapsulated with maltodextrin per liter (T3), and yogurt added with $600 \mathrm{mg}$ of beet extract encapsulated with inulin per liter (T4). Treatments were kept in refrigeration $\left(4^{\circ} \mathrm{C}\right)$ for 14 days, taking samples on days 1,7 , and 14 to evaluate color, $\mathrm{pH}$, syneresis, betalains, and polyphenols content and antioxidant activity. On day 1, physicochemical analysis (fat, protein, moisture, and ash content) of yogurts were determined.

\subsubsection{Physicochemical Analysis}

The chemical composition of the yogurt samples corresponding to day 1 . Moisture, ash, fat, and protein content were determined in triplicate according to the methods established by the AOAC (926.08, 935.42, 989.05, and 991.20, respectively).

\subsection{2. $\mathrm{pH}$ and Syneresis}

The $\mathrm{pH}$ was measured in $20 \mathrm{~g}$ of each sample with a digital potentiometer (Orion Versa Star) previously calibrated and syneresis was evaluated using the method described by Özturk and Óner [78]; $10 \mathrm{~g}$ of yogurt were taken $\left(4 \pm 1^{\circ} \mathrm{C}\right)$, placed in Corning UHP tubes $(50 \mathrm{~mL})$, and centrifuged (Avanti Model J-26 XPI Beckman Coulter ${ }^{\circledR}$ centrifuge, USA) at $2800 \times g$ for $10 \mathrm{~min}$, at $4 \pm 1{ }^{\circ} \mathrm{C}$. The supernatant was weighed and expressed as a percentage in relation to the initial weight of the yogurt.

\subsubsection{Color}

Color was measured with a Model CR-410 colorimeter (Konica Minolta ${ }^{\circledR}$, Japan) evaluating the $L^{*}, a^{*}$ and $b^{*}$ parameters. Where $L^{*}$ is an indicator of luminosity (from black to white), $\mathrm{a}^{*}$ is an indicator that goes from green (negative values) to red (positive values), and $b^{*}$ indicates shades from blue (negative values) to yellow (positive values). The samples were placed in plastic containers with a capacity of $200 \mathrm{~mL}$. The determinations were made in triplicate, and the $L^{*}, a^{*}$, and $b^{*}$ values were used to calculate Chroma* $\left(C^{*}\right)$, Hue angle $\left(\mathrm{h}^{\circ}\right)$, and $\Delta \mathrm{E}$. 
The Chroma value indicates the intensity or color saturation and was determined using the following equation [62]:

$$
\text { Chroma }=\left(a^{* 2}+b^{* 2}\right)^{1 / 2}
$$

Hue angle refers to hues and can range from $0^{\circ}$ (pure red), $90^{\circ}$ (pure yellow), $180^{\circ}$ (pure green), and $270^{\circ}$ (pure blue). This parameter was calculated using the following equation [62]:

$$
H u e^{\circ}=\arctan \left(b^{*}+a^{*}\right)
$$

For the yogurt color difference (represented as $\Delta E^{*}$ ) in each of the treatments, the average of the readings of the parameters $\mathrm{L}^{*}, a^{*}$ and $b^{*}$ was used using the following equation, and the control treatment was the reference of the readings [79]:

$$
\Delta E=\sqrt{\left(L_{s}-L_{c}\right)^{2}+\left(a h_{s}-a h_{c}\right)^{2}+\left(b h_{s}-b h_{c}\right)^{2}}
$$

where $L_{\mathcal{c}}, a h_{c}$, and $b h_{c}=$ control parameters and $L_{s}, a h_{s}$, and $b h_{s}=$ parameters for the different treatments.

\subsubsection{Yogurt Aqueous Extract}

To obtain the aqueous extract, the methodology reported by Torres-Llanez et al. [80] was applied, with the modification (or elimination) of the preparation or conditioning of the sample. Briefly, $50 \mathrm{~mL}$ of each treatment was placed in plastic tubes (for centrifuge) and centrifuged (Avanti ${ }^{\circledR}$ J-26 XPI. Beckman Coluter ${ }^{\circledR}$, USA) at $10,000 \times g$ for 30 min at $4{ }^{\circ} \mathrm{C}$. The supernatant (aqueous extract) was filtered with Whatman ${ }^{\mathrm{TM}}$ filter paper (GE Healthcare, UK) with $125 \mathrm{~mm}$ pore diameter. Said extract was centrifuged again with the conditions mentioned above. The supernatants were filtered through a $0.22 \mu \mathrm{m}$ pore polyethylene filters for the determination of antioxidant capacity and polyphenol content (Millipore Corp., Bedford, MA, USA). To determine betalain content, the extract was filtered on $0.45 \mu \mathrm{m}$ pore paper (Millipore Corp., Bedford, MA, USA). All extracts were stored at $-20{ }^{\circ} \mathrm{C}$ until analysis.

\subsubsection{Antioxidant Activity}

Antioxidant activity by the ABTS (2,2'-azino-bis (3-ethylbenzothiazoline-6-sulfonic acid)) methodology was conducted according to Thaipong et al. [81]. First, an ABTS $7.4 \mathrm{mM}$ solution was elaborated $(38.8 \mathrm{mg}$ of crystallized ammonium salt of ABTS in $10 \mathrm{~mL}$ of distilled water). Next, a solution $2.6 \mathrm{mM}$ of potassium persulfate was prepared $(6.6 \mathrm{mg}$ in $10 \mathrm{~mL}$ with distilled water). Then, these two solutions were then combined and let to stand at room temperature for $12 \mathrm{~h}$ in the dark. To make the ABTS working solution, $1 \mathrm{~mL}$ of ABTS free radical solution was added to $60 \mathrm{~mL}$ of methanol to get an absorbance of $1.1+0.02$. After that, in a $3 \mathrm{~mL}$ plastic cell, $150 \mu \mathrm{L}$ of the standard (Trolox) or sample and $2850 \mu \mathrm{L}$ of ABTS working solution were placed and let to stand for $2 \mathrm{~h}$ at room temperature in the dark; then, the absorbance was measured with a UV spectrophotometer at $734 \mathrm{~nm}$ (UV-1800. Shimadzu, Japan). Measurements were conducted three times. Antioxidant activity was given as equivalent $\mathrm{mM}$ Trolox $(\mathrm{mM} \mathrm{TE} / 100 \mathrm{~g})$. The resulting absorbance was then put into the regression equation $\left(y=-1.0726 x+0.9863 ; r^{2}=0.9967\right)$ derived from the Trolox calibration curve.

Antioxidant activity by the DPPH (2,2-diphenyl-1-picrylhydrazyl) methodology was realized according to Thaipong et al. [81] with slight modifications. First, a $0.6 \mathrm{mM}$ DPPH stock solution was elaborated $(0.0240 \mathrm{~g}$ of DPPH in $100 \mathrm{~mL}$ of methanol) to get a concentration of $0.6 \mathrm{mM}$. This stock solution was kept in the dark and frozen at $-20{ }^{\circ} \mathrm{C}$ until used. To obtain the working solution, $10 \mathrm{~mL}$ of the stock solution was mixed with methanol $(45 \mathrm{~mL})$ to get an absorbance of $1.1+0.02$ and a final concentration of $0.1 \mathrm{mM}$. Later, in a $3 \mathrm{~mL}$ quartz cell, $150 \mu \mathrm{L}$ of standard (Trolox) or sample and $2850 \mu \mathrm{L}$ of the $\mathrm{DPPH}$ working solution were sited and let to stand in the dark at room temperature for 
$3 \mathrm{~h}$. Finally, the absorbance was measured at $515 \mathrm{~nm}$ on a UV spectrophotometer (UV-1800. Shimadzu, Japan). Measurements were conducted three times. Antioxidant capacity was given as equivalent $\mathrm{mM}$ Trolox ( $\mathrm{mM}$ TE/100 $\mathrm{g}$ ). The resulting absorbance was then put into the regression equation $\left(y=-1.3055 x+1.1077 ; r^{2}=0.9994\right)$ derived from the Trolox calibration curve.

The ABTS and DPPH standard curves were executed according to Thaipong et al. [81] methodology. A stock solution (31.3 mg of Trolox (6-hydroxy-2,5,7,8-tetramethylchroman2-carboxylic acid) in $10 \mathrm{~mL}$ of methanol) was made and 1.20, 1.00, 0.80, 0.60, 0.40, 0.20, 0.10, $0.08,0.05$, and $0.03 \mathrm{mM}$ dilutions were used to obtain the curves.

\subsubsection{Polyphenols Content}

The polyphenols content was determined according to Singleton and Rossi [82] with some modifications, following the Folin-Ciocalteu spectrophotometric method employing gallic acid (GA) as a standard. First, a solution of a sample extract (50 $\mu \mathrm{L})$, distilled water $(3 \mathrm{~mL})$, Folin-Ciocalteu reagent $(250 \mu \mathrm{L})$, and sodium carbonate solution at $7 \%(750 \mu \mathrm{L})$ was prepared and stirred for $10 \mathrm{~s}$ and let to stand at room temperature for $8 \mathrm{~min}$. Next, distilled water $(950 \mu \mathrm{L})$ was added, and the mixes were left in the dark at room temperature for $2 \mathrm{~h}$. Finally, in a UV spectrophotometer (UV-1800. Shimadzu, Japan), the absorbance was taken. Triplicate measurements were taken. The absorbance measurements were linearized using the calibration curve's regression equation $\left(y=0.0929 x-0.0197 ; r^{2}=0.9991\right)$ and reported in $\mathrm{mg}$ gallic acid equivalent (mg GAE/g).

The standard curve for polyphenols content was obtained following $\mathrm{Xu}$ and Chang, 2007 [83] methodology. For this, a stock solution was made ( $0.5 \mathrm{~g}$ of gallic acid in $250 \mathrm{~mL}$ of distilled water) and 400, 300, 200, 150, 100, 80, 60, 40, and 20 ppm concentrations were prepared to elaborate the standard curve.

\subsubsection{Extraction of Betalains}

The extraction of betalains was done according to Güneşer [84]. For this, $4 \mathrm{~mL}$ of the aqueous extract and $4 \mathrm{~mL}$ of trichloroacetic acid (TCA) solution at $4 \%$ concentration were placed and mixed in Corning tubes. Then, solutions were homogenized for $3 \mathrm{~min}$ with a vortex (Ultra-Turrax IKA T18 basic) and centrifuged at $4032 \times g$ (Avanti ${ }^{\circledR} \mathrm{J}-26$ XPI. Beckman Coluter ${ }^{\circledR}$, Indianapolis, IN, USA) for $10 \mathrm{~min}$ at $25^{\circ} \mathrm{C}$. Finally, using a $0.45 \mu \mathrm{m}$ pore polyethylene filter (Millipore Corp., Bedford, MA, USA) supernatants were filtered through. Samples were stored at $-20{ }^{\circ} \mathrm{C}$ for further analysis.

\subsubsection{Total Betalains Content}

Total betalains content was determined according to Ruíz-Gutiérrez et al. [62]. McIlvaine buffer ( $\mathrm{pH}$ 6.5, citrate-phosphate in a 1 to 10 ratio) was used to dilute the aqueous extracts of $\mathrm{T} 2$. This dilution was not required for $\mathrm{T} 3$ and $\mathrm{T} 4$ to produce values at their respective absorption maxima. The following formula was used to compute TB:

$$
B[\mathrm{mg} / \mathrm{g}]=[(A \times D F \times M W \times V) /(\varepsilon \times L)]
$$

where $A=$ value at maximum absorption (534 for $\mathrm{BC}$ and 480 for $\mathrm{BX}$ ) at $600 \mathrm{~nm}, \mathrm{DF}=$ dilution factor, $M W=$ molecular weight $(550 \mathrm{~g} / \mathrm{mol}$ for $\mathrm{BC}$ and $308 \mathrm{~g} / \mathrm{mol}$ for $\mathrm{BX}), V=$ volume of the solution $(1000 \mathrm{~mL}), \varepsilon=$ molar extinction coefficient $\left(60,000 \mathrm{Lmol}^{-1} \mathrm{~cm}^{-1}\right.$ for BC and $48,000 \mathrm{Lmol}^{-1} \mathrm{~cm}^{-1}$ for BX), and $L=$ length of the reading cell $(1 \mathrm{~cm})$.

$\mathrm{BC}$ and $\mathrm{BX}$ quantifications were done separately, and the findings were combined to get the BT content. These determinations were done in triplicate, and the results were expressed in milligrams per $100 \mathrm{~g}$ of powder.

\subsubsection{Total Protein Concentration}

The total protein concentration was evaluated following the methodology of Bradford [85]. For this, $0.1 \mathrm{~mL}$ of the sample and $1 \mathrm{~mL}$ of the Bradford reagent were mixed and let to stand in the dark for $45 \mathrm{~min}$. After that, absorbance was read at $595 \mathrm{~nm}$ in a 
spectrophotometer (UV-1800 Shimadzu). The absorbance measurements were linearized using the calibration curve's regression equation $\left(y=0.1526 x-0.0597 ; r^{2}=0.9973\right)$ and reported in $\mu / \mathrm{mL}$ of BSA.

For the calibration curve, bovine serum albumin (BSA) at different concentrations $(1.20,1.00,0.80,0.60,0.40,0.20$, and $0.10 \mathrm{mM}$.) were prepared and the absorbance of these were linearized to obtain the regression equation of the calibration curve.

\subsubsection{Statistical Analysis}

All analyses were conducted using SAS 9.0 program (Institute Inc., Cary, NC, USA, 2006). To determine the type, strength, and significance of their linear association, an analysis of correlations between pairs of response variables was performed, using the CORR procedure. Yogurts proximal analysis were analyzed using the ANOVA procedure, through the following model:

$$
Y i j=\mu+T i+\varepsilon i j .
$$

where $Y i j=$ response variable measured in the $j$-th repetition of the $i$-th treatment, $\mu$ = general mean common to all observations, $\mathrm{T} i=$ effect of the $i$-th treatment, and $\varepsilon i j=$ random error measured in the $j$-th repetition of the $i$-th treatment, which was assumed to be identically and independently distributed in a normal way with mean $\mu$ and variance $\sigma 2$. When there were differences across treatments, the Tukey's and Duncan's tests were used to perform a multiple comparison of means.

For the analysis of the physical characteristics (color, $\mathrm{pH}$, and syneresis) and the bioactivities (antioxidant, betalains, and polyphenols) measured over time, an analysis was carried out with the MIXED procedure, based on the following model:

$$
Y i j k=\mu+T i+P j+\varepsilon i j k
$$

where $Y i j=$ response variable measured in the $k$-th repetition of the $i$-th treatment evaluated in the $j$-th storage time, $\mu=$ general mean common to all observations, $T i=$ effect of the $i$-th treatment, $P j=$ effect of $j$-th storage time, and $\varepsilon i j k=$ random error measured in the $j$-th repetition of the $i$-th treatment evaluated in the $j$-th storage time, which was assumed to be identically and independently distributed in a normal way with mean $\mu$ and variance $\sigma 2$.

\section{Conclusions}

The results of this research confirm that beet extracts (liquid or lyophilized) can be added to yogurt to increase its functional properties. The addition of beet extracts significantly increased the antioxidant activity of the yogurts; where betalains and other polyphenols are the main compounds responsible for said bioactivity. Meanwhile, encapsulation of beet extract by lyophilization turned out to be an effective method to stabilize betalains. However, it was not possible to determine whether maltodextrin or inulin was better as an encapsulating agent, as the AA of the yogurt added with these varies during storage time. The mechanisms that affect antioxidant activity during fermentation are considerably varied; therefore, it is recommended to study the AA of yogurts added with liquid and/or lyophilized beet extract, with the same betalain content to obtain comparable results. The shelf life of the product could be increased to observe the behavior of betalains and polyphenols in yogurt after 14 days. In addition, it would be interesting to carry out the microbiological and economic study of this yogurt.

Author Contributions: Conceptualization, M.A.F.-M. and A.C.-M.; data curation, E.S.-E.; formal analysis, M.A.F.-M. and E.S.-E.; funding acquisition, A.C.-M.; investigation, M.A.F.-M. and R.S.-V.; methodology, M.G.R.-G.; project administration, A.C.-M.; supervision, M.G.R.-G., R.S.-V. and A.C.M.; writing-original draft, M.A.F.-M.; writing-review and editing, M.G.R.-G., R.S.-V., E.S.-E. and A.C.-M. All authors have read and agreed to the published version of the manuscript.

Funding: This research received no external funding. 
Institutional Review Board Statement: Ethical review and approval were waived for this study, due to yogurt was elaborate with pasteurized milk and it does not represent a risk to the health of the participants.

Informed Consent Statement: Informed consent was obtained from all subjects involved in the study.

Data Availability Statement: The data presented in this study are available on request from the corresponding author.

Acknowledgments: The authors acknowledge that the Universidad Autónoma de Chihuahua supported this investigation. The Science and Technology National Council of Mexico (CONACYT) provided a graduate study scholarship for Martha Azucena Flores Mancha.

Conflicts of Interest: The authors declare no conflict of interest.

Sample Availability: Samples of the compounds ...... are available from the authors.

\section{References}

1. Salmerón, I. Fermented cereal beverages: From probiotic, prebiotic and synbiotic towards Nanoscience designed healthy drinks. Lett. Appl. Microbiol. 2017, 65, 114-124. [CrossRef] [PubMed]

2. Shah, N.P. Functional cultures and health benefits. Int. Dairy J. 2007, 17, 1262-1277. [CrossRef]

3. Flores-Mancha, M.A.; Ruiz-Gutiérrez, M.G.; Renteria-Monterubio, A.L.; Sanchez-Vega, R.; Juarez-Moya, J.; Santellano-Estrada, E.; Chavez-Martinez, A. Stirred yogurt added with beetrot extracts as an antioxidant source: Rheological, sensory, and physicochemical characteristics. J. Food Process. Preserv. 2021, 53, 1689-1699. [CrossRef]

4. Muniandy, P.; Shori, A.B.; Baba, A.S. Influence of green, white and black tea addition on the antioxidant activity of probiotic yogurt during refrigerated storage. Food Packag. Shelf Life 2016, 8, 1-8. [CrossRef]

5. Cho, W.Y.; Kim, D.H.; Lee, H.J.; Yeon, S.J.; Lee, C.H. Quality characteristic and antioxidant activity of yogurt containing olive leaf hot water extract. CYTA J. Food 2020, 18, 43-50. [CrossRef]

6. Hong, H.; Son, Y.-J.; Kwon, S.-H.; Kim, S. Biochemical and antioxidant activity of yogurt supplemented with paprika juice of different colors. Food Sci. Anim. Resour. 1390, 40, 613-627. [CrossRef]

7. Shori, A.B. Proteolytic activity, antioxidant, and $\alpha$-Amylase inhibitory activity of yogurt enriched with coriander and cumin seeds. LWT 2020, 133, 109912. [CrossRef]

8. Sabeena-Farvin, K.H.; Baron, C.P.; Nielsen, S.; Otte, J.; Jacobsen, C. Antioxidant activity of yoghurt peptides: Part 2Characterisation of peptide fractions. Food Chem. 2010, 123, 1090-1097. [CrossRef]

9. Cho, W.; Yeon, S.; Hong, G.; Kim, J. Antioxidant activity and quality characteristics of yogurt added Green olive powder during storage. Korean J. Food Sci. Anim. Res. 2017, 37, 865-872.

10. Yeon, S.; Hong, G.; Kim, C.; Park, W.J.; Kim, S.; Lee, C. Effects of yogurt containing fermented pepper juice on the body fat and cholesterol level in high fat and high cholesterol diet fed rat. Korean J. Food Sci. An. Res. 2015, 35, 479-485. [CrossRef]

11. Parra-Huertas, R.A. Effect of green tea (Camellia sinensis L.) on the physicochemical, microbiological, proximal and sensory characteristics of yogurt during refrigerated storage. Aliment. Cienc. Tecnol. Aliment. 2013, 11, 56-64.

12. Ramos-Arrieta, K.; Zabaleta, K.; Granados-Conde, C. Preparation of a Standardized Yogurt with the Addition of Hibiscus Sabdariffa (Jamaica Flower) with Antioxidant Functional. Property Thesis, Universidad de Cartagena, Bolívar, Colombia, 2013. Available online: https:/ / repositorio.unicartagena.edu.co (accessed on 20 July 2021).

13. Šeregelj, V.; Pezo, L.; Šovljanski, O.; Lević, S.; Nedović, V.; Markov, S.; Tomić, A.; Čanadanović-Brunet, J.; Vulić, J.; Šaponjac, V.T.; et al. New concept of fortified yogurt formulation with encapsulated carrot waste extract. LWT Food Sci. Technol. 2020, 138, 110732. [CrossRef]

14. Gies, M.; Descalzo, A.M.; Servent, A.; Dhuique-Mayer, C. Incorporation and stability of carotenoids in a functional fermented maize yogurt-like product containing phytosterols. LWT 2019, 111, 105-110. [CrossRef]

15. Delgado-Vargas, F.; Jiménez, A.R.; Paredes-López, O. Natural pigments: Carotenoids, anthocyanins, and betalainsCharacteristics, biosynthesis, processing, and stability. Crit. Rev. Food Sci. Nutr. 2000, 40, 173-289. [CrossRef] [PubMed]

16. Soriano-Santos, J.; Franco-Zavaleta, M.; Pelayo-Zaldivar, C.; Armella-Villalpando, M.; Yañez-López, M.; Guerrero-Legarreta, I. Partial characterization of the red pigment of the "Jiotilla" fruit (Escontria chiotilla [Weber] Britton \& Rose). Rev. Mex. Ing. Química 2007, 6, 19-25. [CrossRef]

17. Rodriguez-Amaya, D.B. Natural food pigments and colorants. Curr. Opin. Food Sci. 2016, 7, 20-26. [CrossRef]

18. Kanner, J.; Harel, S.; Granit, R. Betalains-A New class of dietary cationized antioxidants. J. Agric. Food Chem. 2001, 49, 5178-5185. [CrossRef]

19. Kapadia, G.J.; Azuine, M.A.; Sridhar, R.; Okuda, Y.; Tsuruta, A.; Ichiishi, E.; Mukainake, T.; Takasaki, M.; Konoshima, T.; Nishino, H.; et al. Chemoprevention of DMBA-induced UV-B promoted, NOR-1-induced TPA promoted skin carcinogenesis, and DEN-induced phenobarbital promoted liver tumors in mice by extract of beetroot. Pharmacol. Res. 2003, 47, 141-148. [CrossRef]

20. Gandía-Herrero, F.; García-Carmona, F. Biosynthesis of betalains: Yellow and violet plant pigments. Trends Plant Sci. 2013, 18, 334-343. [CrossRef] [PubMed] 
21. Gandía-Herrero, F.; Cabanes, J.; Escribano, J.; García-Carmona, F.; Jiménez-Atiénzar, M. Encapsulation of the most potent antioxidant betalains in edible matrixes as powders of different colors. J. Agric. Food Chem. 2013, 61, 4294-4302. [CrossRef]

22. Kapadia, G.J.; Subba, R.G. Red Beet Biotechnology; Neelwarne, B., Ed.; Springer: New York, NY, USA, 2013 ; ISBN 9781461434573.

23. Gandía-Herrero, F.; Escribano, J.; García-Carmona, F. Biological activities of plant pigments betalains biological activities of plant pigments betalains. Crit. Rev. Food Sci. Nutr. 2016, 56, 937-945. [CrossRef] [PubMed]

24. Mikołajczyk-Bator, K.; Pawlak, S. The effect of thermal treatment on antioxidant capacity and pigment contents in separated betalain fractions. Acta Sci. Pol. Technol. Aliment. 2016, 15, 257-265. [CrossRef]

25. Ciriminna, R.; Fidalgo, A.; Danzì, C.; Timpanaro, G.; Ilharco, L.M.; Pagliaro, M. Betanin: A bioeconomy insight into a valued betacyanin. ACS Sustain. Chem. Eng. 2018, 6, 2860-2865. [CrossRef]

26. Martínez, L.; Cilla, I.; Beltrán, J.A.; Roncalés, P. Comparative effect of red yeast rice (Monascus purpureus), red beet root (Beta vulgaris) and betanin (E-162) on colour and consumer acceptability of fresh pork sausages packaged in a modified atmosphere. J. Sci. Food Agric. 2006, 86, 500-508. [CrossRef]

27. Carocho, M.; Morales, P.; Ferreira, I.C.F.R. Natural food additives: Quo vadis? Trends Food Sci. Technol. 2015, 45, 284-295. [CrossRef]

28. Von Elbe, J.H.; Young-Maing, I.; Amundson, C.H. Color stability os betanin. J. Food Sci. 1974, 39, 334-337. [CrossRef]

29. Huang, A.; Von Elbe, J. Kinetics of the degradation and regeneration of betanine. J. Food Sci. 1985, 50, 1115-1120. [CrossRef]

30. Penfield, M.; Campbell, A. Fruits and vegetables. In Experimental Food Science; Academic Press: San Diego, CA, USA, 1990; Volume 3, pp. 294-330.

31. Reyes-Aguilar, S.L. Processing Effect on the Stability of Polyphenols in Mango Extract (Mangifera indica L.). Thesis, Escuela Agrícola Panamericana, Tegucigalpa, Honduras, 2014. Available online: https://bdigital.zamorano.edu/bitstream/11036/3374 /1/AGI-2014-T038.pdf (accessed on 20 July 2021).

32. Slimen, I.B.; Najar, T.; Abderrabba, M. Chemical and antioxidant properties of betalains. J. Agric. Food Chem. 2017, 65, 675-689. [CrossRef] [PubMed]

33. Von Elbe, J.; Schwartz, S. Colorants. In Food Chemistry; Marcel Dekker: New York, NY, USA, 1996; Volume 651, p. 722.

34. Wong, Y.M.; Siow, L.F. Effects of heat, $\mathrm{pH}$, antioxidant, agitation and light on betacyanin stability using red-fleshed dragon fruit (Hylocereus polyrhizus) juice and concentrate as models. J. Food Sci. Technol. 2015, 52, 3086-3092. [CrossRef] [PubMed]

35. Serris, G.S.; Biliaderis, C.G. Degradation kinetics of beetroot pigment encapsulated in polymeric matrices. J. Sci. Food Agric. 2001, 700, 691-700. [CrossRef]

36. Herbach, K.; Stintzing, F.; Carle, R. Betalain stability and degradation. J. Food Sci. 2006, 71, 41-50. [CrossRef]

37. Herbach, K.M.; Rohe, M.; Stintzing, F.C.; Carle, R. Structural and chromatic stability of purple pitaya (Hylocereus polyrhizus [Weber] Britton \& Rose) betacyanins as affected by the juice matrix and selected additives. Food Res. Int. 2006, 39, 667-677. [CrossRef]

38. Herbach, K.M.; Stintzing, F.C.; Carle, R. Stability and color changes of thermally treated betanin, phyllocactin, and hylocerenin solutions. J. Agric. Food Chem. 2006, 54, 390-398. [CrossRef] [PubMed]

39. Stintzing, F.C.; Trichterborn, J.; Carle, R. Characterisation of anthocyanin-betalain mixtures for food colouring by chromatic and HPLC-DAD-MS analyses. Food Chem. 2006, 94, 296-309. [CrossRef]

40. Martins, N.; Roriz, C.; Morales, P.; Barrosa, L.; Ferreira, I. Coloring attributes of betalains: A key emphasis on stability and future applications. Food Funct. 2017, 8, 1357-1372. [CrossRef] [PubMed]

41. Flores-Mancha, M.A.; Renteria-Monterubio, A.L.; Sanchez-Vega, R.; Chavez-Martinez, A. Structure and stability of betalains. Investig. Y Cienc. 2019, 44, 318-325.

42. Flores-Mancha, M.A.; Ruíz-Gutiérrez, M.G.; Sánchez-Vega, R.; Santellano-Estrada, E.; Chávez-Martínez, A. Characterization of beet root extract (Beta vulgaris) encapsulated with maltodextrin and inulin. Molecules 2020, 25, 5498. [CrossRef]

43. Gandía-Herrero, F.; Escribano, J.; García-Carmona, F. The role of phenolic hydroxy groups in the free radical scavenging activity of betalains. J. Nat. Prod. 2009, 72, 1142-1146. [CrossRef] [PubMed]

44. Obón, J.M.; Castellar, M.R.; Alacid, M.; Fernández-lópez, J.A. Production of a red-purple food colorant from Opuntia stricta fruits by spray drying and its application in food model systems. J. Food Eng. 2009, 90, 471-479. [CrossRef]

45. López, A.; Deladino, L.; Navarro, S.; Martino, M. Encapsulation of bioactive compounds with alginates for the food industry. Aliment. Cienc. Y Tecnol. Aliment. 2012, 10, 18-27.

46. Omae, J.M.; Goto, P.A.; Rodrigues, L.M.; Santos, S.; Paraiso, C.M.; Madrona, G.S.; Bergamasco, D.C. Beetroot extract encapsulated in inulin: Storage stability and incorporation in sorbet. Chem. Eng. Trans. 2017, 57, 1843-1848. [CrossRef]

47. Diaz, Y.L.; Torres, L.S.; Serna, J.A. Effect of encapsulation in drying by atomization of biocomponents of yellow pitahaya with functional interest. Inf. Tecnol. 2017, 28, 23-34. [CrossRef]

48. Saénz, C.; Tapia, S.; Chávez, J.; Robert, P. Microencapsulation by spray drying of bioactive compounds from cactus pear (Opuntia ficusindica). Food Chem. 2009, 114, 616-622. [CrossRef]

49. Castellar, R.; Obón, J.; Alacid, M.; Fernández-López, J. Color properties and stability of betacyanins from Opuntia fruits. J. Agric. Food Chem. 2003, 51, 2772-2776. [CrossRef] [PubMed]

50. Parra-Huertas, R. Evaluacion fisicoquimica, proximal y sensorial de una bebida lactea fermentada con concentrado de rubas (Ullucus tuberosus). Vitae 2012, 19, 225-227. 
51. Sanchez, N.; Sepulveda, J.; Rojano, B. Development of a milk drink with extracts of curuba (Passiflora mollissima Bailey) as a natural antioxidant. Biotecnol. Sect. Agropecu. Agroind. 2013, 11, 164-173.

52. Parra-Huertas, R. Physicochemical, sensory, proximal and microbiological characteristics of yoghurt with. Temas Agrar. 2014, 19, 146-158.

53. Parra-Huertas, R.A. Use of Rubas (Ullucus tuberosus) in the elaboration and characterization of a yogurt. Temas Agrar. 2015, 20, 91-102. [CrossRef]

54. Hernández-Rodríguez, G.; Salazar-Tijerino, M. Effect of Betalains and Total Soluble Phenols of Pitahaya (Hylocereus polyrhizus) as Antioxidants in Yogurt. Thesis, Escuela Agrícola Panamericana, Tegucigalpa, Honduras, 2017; p. 28. Available online: https:/ / bdigital.zamorano.edu/bitstream/11036/6060/1/AGI-2017-029.pdf (accessed on 20 July 2021).

55. Macedo-Ramírez, R.C.; Vélez-Ruíz, J.F. Physicochemical and flow properties of a seated yogurt enriched with microcapsules containing omega 3 fatty acids. Inf. Tecnol. 2015, 26, 87-96. [CrossRef]

56. Diaz-Jimenez, B.; Sosa-Morales, M.; Velez-Ruiz, J. Effect of the addition of fiber and the reduction of fat on the physicochemical properties of yogurt. Rev. Mex. Ing. Quim. 2004, 3, 287-305.

57. Achanta, K.; Aryana, K.J.; Boeneke, C.A. Fat free plain set yogurts fortified with various minerals. LWT Food Sci. Technol. 2007, 40, 424-429. [CrossRef]

58. Antigo, J.L.D.; Bergamasco, R.D.C.; Madrona, G.S. Effect of ph on the stability of red beet extract (Beta vulgaris 1.) microcapsules produced by spray drying or freeze drying. Food Sci. Technol. 2017, 38, 72-77. [CrossRef]

59. Pitalua, E.; Jimenez, M.; Vernon-Carter, E.J.; Beristain, C.I. Antioxidative activity of microcapsules with beetroot juice using gum Arabic as wall material. Food Bioprod. Process. 2010, 88, 253-258. [CrossRef]

60. Anese, M.; Calligaris, S.; Nicoli, M.C.; Massini, R. Influence of total solids concentration and temperature on the changes in redox potential of tomato pastes. Int. J. Food Sci. Technol. 2003, 38, 55-61. [CrossRef]

61. Sawicki, T.; Wiczkowski, W. The effects of boiling and fermentation on betalain profiles and antioxidant capacities of red beetroot products. Food Chem. 2018, 259, 292-303. [CrossRef]

62. Ruiz-Gutiérrez, M.G.; Amaya-Guerra, C.A.; Quintero-Ramos, A.; Ruiz-Anchondo, T.D.J.; Gutiérrez-Uribe, J.A.; Baez-González, J.G.; Lardizabal-Gutiérrez, D.; Campos-Venegas, K. Effect of soluble fiber on the physicochemical properties of cactus pear (Opuntia ficus indica) encapsulated using spray drying. Food Sci. Biotechnol. 2014, 23, 755-763. [CrossRef]

63. Janiszewska, E. Microencapsulated beetroot juice as a potential source of betalain. Powder Technol. 2014, 264, 190-196. [CrossRef]

64. Castro-Muñoz, R.; Barragán-Huerta, B.; Yáñez-Fernández, J. Use of gelatin-maltodextrin composite as an encapsulation support for clari fi ed juice from purple cactus pear (Opuntia stricta). LWT Food Sci. Technol. 2015, 62, 242-248. [CrossRef]

65. Ayed, L.; Hamdi, M. Manufacture of a beverage from cactus pear juice using "tea fungus" fermentation. Ann. Microbiol. 2015, 65, 2293-2299. [CrossRef]

66. Azeredo, H.; Santos, A.; Souza, A.; Mendes, K.; Andrade, M.I. Betacyanin stability during processing and storage of a microencapsulated red beetroot extract. Am. J. Food Technol. 2007, 2, 307-312. [CrossRef]

67. Attoe, E.L.; von Elbe, J.H. Oxygen involvement in betanin degradation-Oxygen uptake and influence of metal ions. Z. Für. Lebensm. Unters. Und. Forsch. 1984, 179, 232-236. [CrossRef]

68. Huang, A.; Von Elbe, J. Effect of pH on the degradation and regeneration of betanine. J. Food Sci. 1987, 52, 1689-1693. [CrossRef]

69. von Elbe, J.; Attoe, E. Oxygen involvement in betanine degradation-Measurement of active oxygen species and oxidationreduction potentials. Food Chem. 1985, 16, 49-67. [CrossRef]

70. Azeredo, H.M.C. Betalains: Properties, sources, applications, and stability-A review. Int. J. Food Sci. Technol. 2009, 44, 2365-2376. [CrossRef]

71. Gandía-Herrero, F.; Jiménez-Atiénzar, M.; Cabanes, J.; García-Carmona, F.; Escribano, J. Stabilization of the bioactive pigment of opuntia fruits through maltodextrin encapsulation. J. Agric. Food Chem. 2010, 58, 10646-10652. [CrossRef]

72. Ravichandran, K.; Palaniraj, R.; Min, N.; Thaw, M.; Gabr, A.M.M.; Ahmed, A.R.; Knorr, D.; Smetanska, I. Effects of different encapsulation agents and drying process on stability of betalains extract. J. Food Sci. Technol. 2014, 51, 2216-2221. [CrossRef]

73. Jayabalan, R.; Marimuthu, S.; Swaminathan, K. Changes in content of organic acids and tea polyphenols during kombucha tea fermentation. Food Chem. 2007, 102, 392-398. [CrossRef]

74. Khan, M.I. Stabilization of betalains: A review. Food Chem. 2016, 197, 1280-1285. [CrossRef]

75. Castillo-Garrido, I.C. Stability of Betalains in A Dry Mix for Refreshing Beverages, Based on Microencapsulated Pulp and Extract of Purple Prickly Pear (Opuntia Ficus-Indica). Repositorio Universidad de Chile. 2013. Available online: http://repositorio. uchile.cl/bitstream/handle/2250/113994/castillo_ic.pdf?sequence=1\&isAllowed=y (accessed on 20 July 2021).

76. Vergara, C. Extraction and Stabilization of Betalains from Purple Prickly Pear (Opuntia Ficusindica) using Membrane Technology and Microencapsulation, as A Food Coloring. Thesis, Universidad de Chile, Santiago, Región Metropolitana, Chile, 2013. Available online: http:/ / repositorio.uchile.cl/handle/2250/114868 (accessed on 20 July 2021).

77. Nicoli, M.; Anese, M.; Parpinel, M. Influence of processing on the antioxidant properties of fruit and vegetables. Trends Food Sci. Technol. 1999, 10, 94-100. [CrossRef]

78. Özturk, B.; Óner, M. Production and evaluation of yogurt with concentrated grape juice. J. Food Sci. 1999, 64, 530-532. [CrossRef]

79. Aportela-Palacios, A.; Sosa-Morales, M.E.; Vélez-Ruiz, J.F. Rheological and physicochemical behavior of fortified yogurt, with fiber and calcium. J. Texture Stud. 2005, 36, 333-349. [CrossRef] 
80. Torres-Llanez, M.J.; Vallejo-Cordoba, B.; Díaz-Cinco, M.E.; Mazorra-Manzano, M.A.; González-Córdova, A.F. Characterization of the natural microflora of artisanal Mexican Fresco cheese. Food Control 2011, 17, 683-690. [CrossRef]

81. Thaipong, K.; Boonprakob, U.; Crosby, K.; Cisneros-Zevallos, L.; Hawkins Byrne, D. Comparison of ABTS, DPPH, FRAP, and ORAC assays for estimating antioxidant activity from guava fruit extracts. J. Food Compos. Anal. 2006, 19, 669-675. [CrossRef]

82. Singleton, V.; Rossi, J. Colorimetry of total phenolics with phosphomolybdic-phosphotungstic acid reagents. Am. J. Enol. Vitic $1965,16,144-158$.

83. Xu, B.J.; Chang, S.K.C. A comparative study on phenolic profiles and antioxidant activities of legumes as affected by extraction solvents. J. Food Sci. 2007, 72, S159-S166. [CrossRef] [PubMed]

84. Güneşer, O. Pigment and color stability of beetroot betalains in cow milk during thermal treatment. Food Chem. 2016, 196, 220-227. [CrossRef] [PubMed]

85. Bradford, M.M. A rapid and sensitive method for the quantitation microgram quantities of protein utilizing the principle of protein-dye binding. Anal. Biochem. 1976, 254, 248-254. [CrossRef] 